\title{
Macroalgae as Protein Sources-A Review on Protein Bioactivity, Extraction, Purification and Characterization
}

\author{
Mariana Gordalina ${ }^{1,2}$, Helena M. Pinheiro ${ }^{1,2}$, Marília Mateus ${ }^{1,2, * \mathbb{D}}$, M. Manuela R. da Fonseca ${ }^{1,2}$ (D) \\ and M. Teresa Cesário 1,2,* \\ 1 iBB-Institute for Bioengineering and Biosciences and Department of Bioengineering, Instituto Superior \\ Técnico, Universidade de Lisboa, Av. Rovisco Pais, 1049-001 Lisboa, Portugal; \\ mariana.gordalina@tecnico.ulisboa.pt (M.G.); helena.pinheiro@tecnico.ulisboa.pt (H.M.P.); \\ manuela.fonseca@tecnico.ulisboa.pt (M.M.R.d.F.) \\ 2 Associate Laboratory i4HB-Institute for Health and Bioeconomy at Instituto Superior Técnico, Universidade \\ de Lisboa, Av. Rovisco Pais, 1049-001 Lisboa, Portugal \\ * Correspondence: marilia.mateus@tecnico.ulisboa.pt (M.M.); teresa.cesario@tecnico.ulisboa.pt (M.T.C.)
}

Citation: Gordalina, M.; Pinheiro, H.M.; Mateus, M.; da Fonseca, M.M.R.; Cesário, M.T. Macroalgae as Protein Sources-A Review on Protein Bioactivity, Extraction, Purification and Characterization Appl. Sci. 2021, 11, 7969. https:// doi.org/10.3390/app11177969

Academic Editor: Hervé Quiquampoix

Received: 31 July 2021

Accepted: 24 August 2021

Published: 28 August 2021

Publisher's Note: MDPI stays neutral with regard to jurisdictional claims in published maps and institutional affiliations.

Copyright: (c) 2021 by the authors. Licensee MDPI, Basel, Switzerland. This article is an open access article distributed under the terms and conditions of the Creative Commons Attribution (CC BY) license (https:/ / creativecommons.org/licenses/by/ $4.0 /)$.

\begin{abstract}
The increased demand for protein sources combined with a decrease in the available land and water resources have led to a growing interest in macroalgae as alternative protein sources. This review focuses on strategies for macroalgae protein extraction, enrichment and characterization. To date, the protein extraction methods applied to algae include enzymatic hydrolysis, physical processes and chemical extraction. Novel methods, such as pulsed electric field, microwave-assisted, pressurized liquid and supercritical fluid extractions, and the application of smart solvents are discussed. An overview of the use of membranes and other processes to generate high-value protein concentrates from algae extracts is also presented, as well as some examples of the methods used for their characterization. The potential bioactivities from macroalgae-derived proteins and peptides, including novel glycoproteins and lectins, are briefly reviewed.
\end{abstract}

Keywords: macroalgae; seaweed; protein extraction; bioactivity

\section{Introduction}

A "Biorefinery" is defined as a "sustainable and synergetic processing of biomass into marketable food and feed ingredients, products (chemicals and materials) and energy" by the International Energy Agency (IEA) [1]. Different strategies can be integrated to maximize the extraction of valuable components, with subsequent use of the remaining fractions as raw materials for further processing in a cascading approach, while minimizing waste streams. This concept applied to macroalgae adds value to these bioresources and contributes to sustainable development. It is therefore crucial to choose the best available technologies for an efficient sequential separation of valuable seaweed fractions, in particular of seaweed proteins. Seaweed proteins/peptides due to their availability, amino acid composition and bioactive properties constitute a good option to fulfill the increased demand for protein sources. This review records the available technologies for extraction and enrichment of macroalgal proteins, as well as the methods for their characterization.

\subsection{Macroalgae Background}

The term algae refers to a large diversity of unrelated phylogenetic entities, ranging from picoplanktonic cells to macroalgal kelps [2]. In contrast to terrestrial plants that share a common ancestor, algal diversity includes several distantly related groups of mainly photoautotrophic organisms from aquatic habitats. The high diversity of macroalgae at high taxonomic levels and related long evolutionary history displayed by complex phylogeographies are reflected in the observed richness and diversity of algal components. Algal chemistry is largely linked to evolution, but phenotypic modifications can also be a 
result of environmental and biological stimuli as individual populations exhibit phenotypic plasticity and adaptation to their environment. Because they often experience stressful conditions and highly fluctuating environments, most algae possess mechanisms to enable acclimation to stressors (e.g., UV radiation, temperature and salinity) and are able to defend themselves against biological pressures (e.g., competitors, grazers and/or parasites). This wide range of tolerance combined with their specific cellular structure predisposes them to growth and development under both laboratory and industrial conditions [2].

Macroalgae are multicellular algae with thalli-like structures that can adhere to solid underwater surfaces or float freely in water. They inhabit ecosystems with varied salinities, from freshwater rivers, ponds and lakes to brackish estuaries and the open sea and seashores. Compared to other algal groups, such as microalgae, they occupy available space slower, but grow faster and are less vulnerable to grazing and water turbulence [3]. Macroalgae are classified as green, red and brown algae, according to the thallus color derived from natural pigments. Green algae belong to the Chlorophyta phylum and have the same ratio of chlorophyll $a$ to $b$ as terrestrial plants. There are about 4500 species of green algae [4]. Red algae are included in a single class, Rhodophyceae, which consists of two subclasses: Florideophycidae and Bangiophycidae. The red color is attributed to the pigments chlorophyll $a$, phycoerythrin and phycocyanin. There are about 4000-6000 red algae species in over 600 genera [5]. Brown algae are classified as Phaeophyceae and their principal photosynthetic pigments are chlorophyll $a$ and $c, \beta$-carotene and other xanthophylls. Circa 1500-2000 species of brown algae have been identified so far [6]. Marine macroalgae (seaweeds) are vertically distributed from the upper zone (sea surface) to the lower sublittoral zone [7]. In fact, although many species thrive in littoral zones, some red algae inhabit deeper sea areas (over $25 \mathrm{~m}$ below the surface) whereas others are found under rocks, where direct sunlight availability is limited [8]. This is because red algae use a different part of the light spectrum from that used by other algae and thus are able to grow in places where the other algae cannot grow.

Macroalgae are photoautotrophic and therefore use photosynthesis to produce and store organic carbon by using $\mathrm{CO}_{2}$ or $\mathrm{HCO}_{3}^{-}$[9]. The photosynthetic rates of macroalgae highly depend on the species although green and red algae usually have higher rates than their brown counterparts (by 1 or 2 orders of magnitude) [3]. When comparing macroalgae and terrestrial plants, significant differences in the chemical composition can be pinpointed in addition to the physiological and morphological ones. Macroalgae contain the typical polysaccharides, such as mannan, ulvan, carrageenan, agar, laminarin, alginate and fucoidan, which are not found in lignocellulosic terrestrial biomass [5]. Like terrestrial plant biomass, macroalgae generally do not possess high contents of starch and lipids, except for green algae (1-4\% for starch and $0-6 \%$ for lipids). Their lack of lignin makes them less rigid and contributes to the flexibility of their cell wall.

Carbohydrate compounds are abundant in macroalgae. Their contents in green, red and brown algae vary between $25 \%$ and $50 \%, 30 \%$ and $60 \%$, and $30 \%$ and $50 \%$ of their dry weight $(\mathrm{dw})$, respectively [10]. Their composition evidently differs between species. While cellulose is a structural polysaccharide (exists in the cell wall) common to all macroalgae, each group has other typical structural and storage polysaccharides [11]. As the structural polysaccharides, green macroalgae features ulvan [12], while red algae contain either carrageenan (up to $75 \% \mathrm{dw}$ ) or agar (up to $52 \% \mathrm{dw}$ ) [13]. When it comes to brown algae, their major polysaccharide is alginic acid (i.e., alginate). As storage polysaccharides, green and red algae contain starch (floridan starch in the case of red algae) while brown algae have laminarin ( $\beta$-1,3-glucans), which accounts for up to $35 \% \mathrm{dw}$.

It is relevant to note that the composition of macroalgae of the same species can also differ. Local conditions at the collection site, such as light, salinity, nutrients, temperature, pollution and water motion, can considerably influence the metabolite levels and bioactive compound contents. The biological status of the algae (e.g., life cycle, development stage and thallus structure) can also have an impact on their biochemical composition [14]. 


\subsection{Proteins in Seaweed}

Proteins from macroalgae of marine origin have been the focus of several studies due to their potential bioactivity. The protein content varies according to phylum. Brown algae generally have a low protein content ( 3 to $15 \% \mathrm{dw}$ ), which contrasts with the protein content of green ( 9 to $26 \% \mathrm{dw}$ ) and red algae ( 20 to $47 \% \mathrm{dw}$ ) [15-17]. A recent review lists the protein content of macroalgae species from different geographical regions [18]. In the latter phylum, it is worthy to highlight the species belonging to the genus Porphyra, where the protein content can reach $47 \% \mathrm{dw}$ [19]. These concentrations are comparable to those found in high-protein vegetables, namely $(\% \mathrm{dw})$, leafy greens and legumes (mint-30.9; cilantro-22.2; spinach-26.5; cauliflower-29.9; soybean-35 to 40; chickpea-20 to 25) and major cereals (wheat -8 to 15 ; barley -8 to 15 ; rice -7 to 9 ; corn -9 to 12) [20].

The protein content of macroalgae varies within seasonal cycles. One example is the protein content of the red seaweed Palmaria palmata collected at the French Atlantic coast, which showed fluctuations between 9 and $25 \% \mathrm{dw}$ in protein content. The highest values occurred during winter and spring [15]. Seaweed may contain non-proteinic nitrogen, from nitrates, pigments or nucleic acids, which results in an overestimation of their protein content (usually estimated by the Kjeldahl method, with a general Nitrogen-to-Protein conversion factor of 6.25). Specific Seaweed-Nitrogen-to-Protein (SNP) conversion factors for brown, red and green seaweeds have been reported [21]. Detailed essential amino acids (EAA) and non-EAA profiles, total protein content and protein/non-protein nitrogen amounts of four macroalgae species obtained from an integrated multi-trophic aquaculture system in Ria de Aveiro (from ALGAplus Ltd., Ílhavo, Portugal), have been reported [22].

\subsubsection{Phycobiliproteins}

Protein-pigment complexes such as the phycobiliproteins (PBPs) are one of the most important groups of marine proteins. In red seaweed, these complexes are the main light-harvesting pigments and account for up to $50 \%$ of the total protein content [23]. Phycobiliproteins are the only water-soluble algal pigments. They are a family of fluorescent proteins covalently linked to tetrapyrrole groups, known as bilins. They constitute a structure attached to the cytoplasmic surface of thylakoid membranes named phycobilisomes (unlike carotenoids and chlorophylls that are located in the lipid bilayer) [23]. PBPs are grouped into four classes: phycoerythrin (PE), phycocyanin (PC), phycoerythrocyanins (PEC) and allophycocyanin (APC) [14]. The most common phycobiliprotein in many red seaweeds is known as R-phycoerythrin (R-PE). Isolation of PE has been reported from many species, for instance, Gelidium pusillum [24], Grateloupia turuturu $[25,26]$ and Rhodymenia pseudopalmata [27].

\subsubsection{Glycoproteins and Lectins}

Glycoproteins (GPs) are carbohydrate-binding proteins. Glycans can be conjugated to peptide chains by $\mathrm{N}$-glycosyl linkages and/or O-glycosyl linkages. Protein glycosylation can happen co- or post-translation. GPs are located in the cell wall and on cell surfaces or are secreted [14]. A few seaweed glycoproteins have been isolated by hot- or cold-water extraction. GP-rich fractions obtained from Ulva spp. showed a higher content in proteins than in neutral sugars [28]. Extracts of Ulva lactuca with high contents of both carbohydrates and protein suggested the presence of GPs [29]. Yoshiie et al. (2012) [30] have performed the structural analysis of the $\mathrm{N}$-glycans expressed in several seaweed species. The study revealed that only high-mannose glycans were present in the 15 macroalgae addressed (red, brown and green), while the complex type of $N$-glycans containing $\beta 1-2$ xylosyl and $\alpha 1-3$ fucosyl residues, which is encountered in terrestrial plants, was not found. The same authors discovered that the M9 structure is predominant in the N-glycans of the GPs of Zoostera marina and Sargassum fulvellum. Therefore, they claim the interest of both species as good sources of $\mathrm{N}$-glycans used, e.g., as chaperone-like oligosaccharides in protein assembly [31]. 
Phycolectins are a group of carbohydrate-binding proteins in macroalgae. Lectins interact with specific glycan structures that constitute the soluble and membrane-bound glycoconjugates [14]. Seaweeds are particularly good sources of novel lectins. A few examples are griffithsin, a mannose-specific lectin isolated from the red algae Griffithsia spp. [32]; SfL1 and SfL2 from Solieria filiformis [33]; and HRL40 from Halimeda renschii [34]. Although macroalgae phycolectins have been characterized, very little is currently known about their structural and biochemical properties [14].

Arabinogalactan proteins, which belong to the hydroxyproline-rich glycoproteins, have been reported in the cell wall of few species of seaweeds, namely, in the green seaweeds Codium vermilara [35] and C. fragile [36].

\subsubsection{Enzymes}

Seaweeds are rich sources of enzymes. Alkaline phosphatase (Zn-containing metalloproteinase that catalyzes the non-specific hydrolysis of phosphate monoesters) is widely encountered in seaweeds, namely, in Ulva pertusa [37]. Alternative oxidases (proteins involved in the electron flow through the electron transport chain and in the regulation of the mitochondrial retrograde signaling pathway) have also been described, namely, from Caulerpa cylindracea [38]. The fibrinolytic enzyme (trypsin-like serine protease) has also been isolated from green algae, such as Codium fragile and Codium latum [39,40]. Rubisco, a protein that catalyzes carbon dioxide fixation and oxygenation, has been obtained from Kappaphycus alvarezii [41].

\subsubsection{Peptides and Amino Acids}

Although the structure and biological properties of algal proteins are still relatively poorly documented, the amino acid composition of several species of macroalgae is known [42]. Most species contain all the EAA for humans, which may represent about $50 \%$ of the total amino acids. Besides, their proteins are also rich in aspartic and glutamic acid residues ( $22.7 \mathrm{~g} / 100 \mathrm{~g}$ protein in several red algae) [23]. The levels of some amino acid residues, such as threonine, lysine, tryptophan, cysteine, methionine and histidine, are higher than those found in terrestrial plants [18]. Seaweed amino acid analyses have demonstrated profiles similar to those of ovalbumin (52.4\% EAA) and leguminous plants $(41.62 \%$ EAA) $[15,43]$. At this point, it is worth mentioning that the interest in marine proteins may not be directly linked to the proteins themselves, but rather to the bioactivity potential of the peptides that can be derived from them [44,45]. Bioactive peptides usually contain 3-40 amino acid residues, and their activities stem from both their amino acid composition and sequence. They are generated from parent proteins either through digestion processes in the gastro-intestinal tract or produced through fermentation or other processes involving enzymatic hydrolysis [46,47].

The free amino acid fraction of macroalgae is composed primarily of alanine, taurine, omithine, citrulline and hydroxyproline. Laminine, kanoid amino acids and mycosporinelike amino acids have also been found in marine macroalgae [48]. The successful production of bioactive peptides that originated from hydrolyzed proteins of Palmaria palmata, Solieria chordalis, Ulva lactuca and Saccharina longicruris has been reported [49]. 


\subsection{Applications of Macroalgal Proteins and their Derivatives}

Marine macroalgae are rich sources of structurally diverse bioactive compounds with valuable pharmaceutical and biomedical properties. They can also be used as functional health-promoting ingredients in food and feed [50,51]. Besides the benefits, attention must be given to the potential deleterious effects of food and feed derived from contaminated seaweed and to the legislation regulating these applications [51]. The functional properties of proteins are mainly associated with their ability to form and/or stabilize gels and films, foams, emulsions and sols [52]. Macroalgae or macroalgal extracts have shown effects on the immune status and intestinal health of several monogastric farm animal species, including pigs [53], broiler chicken [54] and fish [55]. These bioactive properties could be related to the presence of specific proteins and/or peptides.

\subsubsection{Bioactive Proteins}

Among all the macroalgal proteins, lectins and phycobiliproteins have received particular attention due to their reported biological activities [42]. The main biological activity associated with lectins is their hemagglutinating activity against erythrocytes [42], whereas phycobiliproteins are used in biomolecule labeling for fluorescent immunoassays, immunohistochemistry assays and fluorescence microscopy, and as natural colorants for food and cosmetic applications [56]. Different phycobiliproteins have exhibited antioxidant, antiinflammatory, neuroprotective, hypocholesterolemic, hepatoprotective, antiviral, antitumor, liver-protecting, atherosclerosis treatment, serum-lipid-reducing and lipase-inhibition activities [56]. The bioactivities of several macroalgal proteins are shown in Table 1.

Table 1. The bioactivities of several macroalgal proteins.

\begin{tabular}{|c|c|c|c|}
\hline Species & Type of Protein & Bioactive Activity & Ref. \\
\hline $\begin{array}{l}\text { Bryothamnion triquetrum, Bryothamnion } \\
\text { seaforthii, and Amansia multifida }\end{array}$ & Lectins & Antinociceptive effects. & [42] \\
\hline Codium fragile & Lectins & $\begin{array}{l}\text { Blood typing; characterization of } \\
\text { cell-surface polysaccharides; } \\
\text { lectinosorbent assays for } \\
\text { cell-binding-pattern examinations. }\end{array}$ & [57] \\
\hline $\begin{array}{l}\text { Codium intricatum, Codium latum, and } \\
\text { Codium divaricatum }\end{array}$ & Fibrinolytic enzymes & $\begin{array}{l}\text { Preferentially hydrolyzing } \\
\text { fibrinogen Aa chain. }\end{array}$ & [57] \\
\hline Eucheuma serra & ESA-2 (lectin) & $\begin{array}{c}\text { Colonic carcinogenesis suppression } \\
\text { in mice; growth inhibition of } 35 \\
\text { human cancer cell lines. }\end{array}$ & [42] \\
\hline Eucheuma serra and Galaxaura marginata & Lectins & $\begin{array}{l}\text { Antibacterial activity against the } \\
\text { fish pathogen Vibrio vulnificus. }\end{array}$ & [57] \\
\hline Griffithsia spp. & Novel lectin & Strong anti-HIV activity. & [42] \\
\hline Hypnea cervicornis and Solieria robusta & Lectins & $\begin{array}{l}\text { Anti-inflammatory and mitogenic } \\
\text { activities in mice spleen } \\
\text { lymphocytes; growth inhibition of } \\
\text { mice leukemia cells L1210 and mice } \\
\text { FM3A tumor cells. }\end{array}$ & [42] \\
\hline Hypnea cervicornis & Mucin-binding agglutinin & $\begin{array}{c}\text { Antinociceptive and } \\
\text { anti-inflammatory activity. }\end{array}$ & [42] \\
\hline
\end{tabular}




\subsubsection{Bioactive Peptides}

Bioactive peptides have been shown to possess properties such as opioid, immunomodulatory, antibacterial, antithrombotic and antihypertensive activity [58]; some may also exhibit multifunctional bioactivities (Table 2) [59].

An extensive list of bioactivities of the peptides derived from specified seaweeds, including methodologies for their enzymatic production conditions, respective bioactivity evaluation assays and citations, can be found in [18].

Table 2. The bioactivities of several macroalgal peptides.

\begin{tabular}{|c|c|c|c|}
\hline Species & Peptide & Bioactive Activity & Ref. \\
\hline Bryopsis spp. & Kahalalide F & Antitumoral activity & [57] \\
\hline Galaxaura filamentous & Galaxamide & $\begin{array}{l}\text { Anti-proliferative activity against } \\
\text { human epithelial cancer cell lines }\end{array}$ & {$[60]$} \\
\hline \multirow[b]{2}{*}{ Palmaria palmata } & Asn-Ile-Gly-Gln & Anti-inflammatory activity & [61] \\
\hline & $\begin{array}{c}\text { Val-Tyr-Arg-Thr; Leu-Asp-Tyr; } \\
\text { Leu-Arg-Tyr; Phe-Glu-Gln-Trp-Ala-Ser }\end{array}$ & \multirow{4}{*}{ ACE-I inhibitory activity } & [62] \\
\hline \multirow{2}{*}{ Porphyra yezoensis } & $\begin{array}{c}\text { Ile-Tyr; Met-Lys-Tyr; Ala-Lys-Tyr-Ser-Tyr; } \\
\text { Ley-Arg-Tyr }\end{array}$ & & {$[63]$} \\
\hline & Ala-Lys-Tyr-Ser-Tyr & & [64] \\
\hline \multirow{2}{*}{ Undaria pinnatifida } & Val-Tyr; Ile-Tyr; Phe-Tyr; Ile-Trp & & \multirow{2}{*}{ [65] } \\
\hline & $\begin{array}{l}\text { Val-Tyr; Ile-Tyr; Ala-Trp; Phe-Tyr; Val-Trp; } \\
\text { Ile-Trp; Leu-Trp }\end{array}$ & Anti-hypertensive & \\
\hline
\end{tabular}

\section{Protein Extraction}

\subsection{Challenges and Impact of Cell Structures}

The successful extraction of macroalgal proteins highly depends on their accessibility since most of them are produced intracellularly. Therefore, the complex nature of algal cell walls is the main challenge for the use of seaweed as protein sources. Algal cells possess many intracellular enzymes and proteins [66] and their cell wall is composed of a highly integrated network of biopolymers, mainly polysaccharides, which interact with water and metal cations, amongst other molecules [67]. The cell wall can be divided into three main domains: the fibrillar wall, the amorphous matrix and the glycoprotein domain [23]. The fibrillar polysaccharides and the glycoproteins form a reticulated network that is embedded in the gel-like amorphous matrix. The fibrous part is the most chemically inert and mechanically resistant cell wall component, with cellulose being the most significant compound amongst others such as xylan and hemicellulose. Very little is known about the glycoprotein domain, which is constituted by glycoproteins that contain cellulose-binding domains. The gel-like matrix is made of carboxylic and/or sulfated polysaccharides, like sulfated galactans such as carrageenans and agarans, and usually extends into the intercellular spaces between adjacent cells [23]. Other biopolymers, such as proteins and polymeric phenolics, can also participate in cell wall formation.

The presence of polysaccharide-bound cell wall mucilage, including anionic or neutral polysaccharides, and polyphenols reduce the protein extractability and requires additional steps for fractionation and purification. Polysaccharides induce strong electrostatic interactions [68], whereas polyphenols may form reversible hydrogen bonds with proteins or undergo oxidation. Oxidized phenolic compounds can react with amino acids and form insoluble complexes [69].

The morphology of different seaweed species has also been suggested to be an important factor in protein extraction, with tougher thallus forms reported to require increased processing. The raw biomass from seaweed after harvesting must be preserved by drying or freezing or used fresh as soon as possible to avoid protein degradation [14]. The 
increased protein extractability from oven-dried biomass was suggested to have been due to the decomposition of the phenolic compounds, as well as increased disruption of the anionic or neutral polysaccharides found within the cell wall of the seaweed [46].

The combination of extraction methods and purification techniques is necessary to improve the protein yield. The greater the scale, the bigger the challenge because methods with low time, cost and energy consumption (i.e., environmentally friendly) are required.

\subsection{Conventional Extraction Methods}

As mentioned above (Section 2.1), the extraction and utilization of algal proteins evidently depends on the disruption of the cell wall. To ensure extraction of intracellular proteins, additional stress factors are often applied, which improve the extraction efficiency.

So far, algal proteins have not been fully described, and hence they are simply divided into four main classes based on their solubility, namely, albumins, which are soluble in water; globulins, which are soluble in salt solutions; glutelins, which are soluble in dilute acids or bases; and prolamins, which are soluble in $70 \%$ alcohol in water [66]. Sequential extraction steps are often carried out to ensure the extraction of different types of proteins, unless a specific type is being targeted.

Algal proteins are conventionally extracted by means of aqueous, acid, and alkaline solution-based methods, followed by centrifugation for extract clarification and fractionation and enrichment techniques, such as ultrafiltration, precipitation and/or chromatography [70]. Aiming at the preservation of protein structure and affinity interactions ability, mild extraction conditions at defined $\mathrm{pH}$ ranges may be required [33,71-73].

Physical cell disruption methods, such as osmotic shock, freeze/thawing, shearing or grinding, can enhance the extraction of protein from some seaweeds. The conventional disruption pre-treatments and protein extraction methods are presented in Table 3.

\subsection{Enzyme-Assisted Extraction}

Enzyme-Assisted Extraction (EAE) is often the preferable method to extract proteins and/or their hydrolysates from seaweed [46]. Polysaccharidases can be applied as a cell disruption treatment prior to protein extraction to increase the protein yield. Several polysaccharidases ( $\kappa$-carrageenase, $\beta$-agarase, xylanase and cellulase) have been used in protein extractions from red seaweed species, namely, Chondrus crispus, Gracilaria verrucosa and Palmaria palmata [74]. The use of cocktails that contain multiple hydrolytic activities (cellulase, hemicellulase and $\beta$-glucosidase) for carrageenan, agar, alginate and cellulose is a promising option to increase the extraction yields [75]. The selective degradation of structural proteins, such as glycoproteins of the cell wall, might be possible by using subtilases or serine proteases [76]. Different digestion enzymes have also been used to release bioactive peptides from parent proteins, with chymotrypsin, trypsin and pepsin being the most used [14]. Combining EAE with other processes (e.g., enzymatic hydrolysis combined with alkaline extraction) is usually the go-to approach (Table 3) [77].

Once again, the enzyme choice is highly correlated with the desired end product (e.g., intact proteins, specific proteins or bioactive peptides). Regarding feasibility, every case needs to be looked at individually. If a high enzyme:substrate ratio is required, an enzymatic treatment might not be viable at the industrial scale, particularly due to the cost of the enzymes. 


\subsection{Ultrasound-Assisted Extraction}

Ultrasound-Assisted Extraction (UAE) has been shown to be an attractive technology when used on cellular matrices. It acts by creating compression and decompression through sound waves at frequencies higher than $20 \mathrm{kHz}$. UAE can be applied to numerous food sources, particularly in the modification of plant micronutrients to improve the bioavailability, simultaneous extraction and encapsulation, quenching radical sonochemistry to avoid degradation of the bioactive compounds, as well as to increase the bioactivity of the phenolics and carotenoids by targeted hydroxylation [78]. The bioavailability of seaweed proteins can also be improved by the degradative effect of sonochemistry, which is not produced by the ultrasound waves directly but rather by acoustic cavitation. This happens when the static pressure falls below the vapor pressure of the liquid and the formation and growth of vapor bubbles occurs. Such bubbles, under the subsequent pressure peak, violently collapse, leading to peeling, erosion, particle breakdown and degradation of the solid-liquid surfaces. Solvent penetration into the cells is facilitated, as is the release of the intracellular compounds to the bulk solvent [79].

The application of ultrasound can be divided into two different categories, namely, low intensity-high frequency $(100 \mathrm{kHz}-1 \mathrm{MHz})$ and high intensity-low frequency (between 20 and $100 \mathrm{kHz}$ ) ultrasound, the latter being the type that is typically used for the disruption of cell walls and membranes [80]. Higher extraction yields are usually achieved at shorter processing times and lower temperatures, making this method suitable for the extraction of thermolabile compounds [81]. Under these conditions, solvent consumption is also lower, facilitating the downstream processing of the target compounds [82].

An ultrasound pre-treatment reportedly increased protein extraction from Ascophyllum nodosum by $540 \%$ and $27 \%$ when followed by acid or alkaline treatment, respectively, when compared with extraction performed with no pre-treatment. It also resulted in a reduced processing time (from 60 to $10 \mathrm{~min}$ ). Extraction of R-phycoerythrin has been deemed effective by combining EAE and UAE in Grateloupia turuturu [26], due to a synergistic effect. In Gelidium pusillum, UAE followed by maceration and extraction in phosphate buffers allowed the recovery of $77 \%$ and $93 \%$ of R-PE and R-phycocyanin (R-PC), respectively [83]. Some examples are presented in Table 3. 
Table 3. The conventional, enzyme-assisted and ultrasound-assisted cell disruption and protein extraction methods applied to different seaweeds.

\begin{tabular}{|c|c|c|c|c|c|c|c|c|}
\hline $\begin{array}{l}\text { Cell Dis- } \\
\text { ruption } \\
\text { Method }\end{array}$ & Extraction Method & Reagents/Buffers & Conditions & Species & $\begin{array}{l}\text { Initial } \\
\text { Protein } \\
\text { Content }\end{array}$ & $\begin{array}{l}\text { Protein } \\
\text { Recovery } \\
\text { Yield }\end{array}$ & $\begin{array}{l}\text { Protein } \\
\text { Quantifi- } \\
\text { cation } \\
\text { Method }\end{array}$ & Ref. \\
\hline \multirow{3}{*}{$\begin{array}{l}\text { Enzymatic } \\
\text { hydrolysis }\end{array}$} & $\begin{array}{l}\text { Polysaccharidase } \\
\text { degradation and buffer }\end{array}$ & $\begin{array}{l}\text { Phosphate buffer, } \\
\text { commercial mixture } \\
\text { of polysaccharidases }\end{array}$ & $\begin{array}{l}\text { Enzymatic pre-treatment } \\
10 \mathrm{~g} \text { freeze-dried algal powder; } 200 \mathrm{~mL} \text { of enzymatic medium, } \mathrm{pH} 6(6 \mathrm{~g} \text { of polysaccharidase powder in } 200 \mathrm{~mL} \text { of phosphate } \\
\text { buffer } 0.1 \mathrm{M}, \mathrm{pH} 6) ; 30^{\circ} \mathrm{C} ; 2 \mathrm{~h} \text {. }\end{array}$ & Ulva rigida & $\begin{array}{l}112.0 \pm 5.8 \\
\mathrm{~g} \mathrm{~kg} \mathrm{dw}_{-1}^{-1}\end{array}$ & $\begin{array}{l}18.5 \pm \\
2.1 \% \\
\mathrm{a}^{\mathrm{a}}\end{array}$ & \multirow{2}{*}{$\begin{array}{l}\text { Kjeldahl } \\
\text { method } \\
(\mathrm{N} \times 6.25)\end{array}$} & \multirow{2}{*}[84]{} \\
\hline & treatment (sequential) & $\begin{array}{l}\text { containing cellulase, } \\
\text { hemilecllulase and } \\
\beta \text {-glucanase, } \\
\text { Tris-HCl. }\end{array}$ & $\begin{array}{l}\text { Buffer treatment } \\
\text { After filtration through a nylon mesh, the residue was ground with a pestle and a mortar in } 100 \mathrm{~mL} \text { Tris- } \mathrm{HCl}(0.1 \mathrm{M}, \mathrm{pH} 7.5) ; 4^{\circ} \mathrm{C} \text {. } \\
\text { Supernatant collected after centrifugation }\left(10,000 \times g, 20 \mathrm{~min}, 4^{\circ} \mathrm{C}\right) \text {. }\end{array}$ & $\begin{array}{l}\text { Ulva } \\
\text { rotundata }\end{array}$ & $\begin{array}{l}100.1 \pm 4.9 \\
\mathrm{~g} \mathrm{~kg} \mathrm{dw}^{-1}\end{array}$ & $\begin{array}{l}22.0 \pm \\
1.5 \%\end{array}$ & & \\
\hline & $\begin{array}{l}\text { Polysaccharidase } \\
\text { degradation and } \\
\text { alkaline treatment } \\
\text { (sequential) }\end{array}$ & $\begin{array}{l}\text { Deionized water, } \\
\text { Cellulase and } \\
\text { xylanase (Cellu- } \\
\text { clast/Shearyyme), } \\
\mathrm{NaOH} \text { and NAC. }\end{array}$ & $\begin{array}{l}\text { Enzymatic pre-treatment } \\
1: 30(w / v) \text { of dried milled seaweed to liquid suspension at } \mathrm{pH} 5 \text { was pre-incubated }\left(30 \mathrm{~min}, 40^{\circ} \mathrm{C}\right) \text {. Enzyme:substrate }(\mathrm{E}: \mathrm{S}) \text { of } \\
48.0 \cdot\left(1^{3} \text { units } 100 \mathrm{~g} \text {, reaction system incubated at } 40^{\circ} \mathrm{C} ; 24 \mathrm{~h} \text {. The supernatant was collected following centrifugation at } 11,950 \times\right. \\
g, \text { room temperature. } \\
\text { Alkaline treatment } \\
\text { Pellet resuspended; weight:volume of } 1: 15 ; 0.12 \mathrm{M} \mathrm{NaOH} ; 0.1 \%(w / v) \mathrm{NAC} \text {; stirred for } 1 \mathrm{~h} \text {; room temperature. Supernatant } \\
\text { collected after centrifugation }(11,950 \times g, 20 \mathrm{~min}, \text { room temperature). }\end{array}$ & $\begin{array}{c}\text { Palmaria } \\
\text { palmata }\end{array}$ & $\begin{array}{c}\text { Not } \\
\text { specified. }\end{array}$ & $\begin{array}{l}11.6 \pm \\
0.08 \% \\
\mathrm{dw} \mathrm{w}^{\mathrm{b}}\end{array}$ & $\begin{array}{c}\text { Lowry } \\
\text { method } \\
\text { (modified) }\end{array}$ & [77] \\
\hline \multirow{4}{*}{$\begin{array}{l}\text { High } \\
\text { shear } \\
\text { force }\end{array}$} & \multirow[t]{2}{*}{$\begin{array}{l}\text { Aqueous treat-ment, } \\
\text { Potter homogenization } \\
\text { and alkaline treatment }\end{array}$} & \multirow[t]{2}{*}{$\begin{array}{l}\text { Ultra-pure water, } \\
\mathrm{NaOH}\end{array}$} & \multirow{2}{*}{$\begin{array}{l}\text { Aqueous treatment } \\
50 \mathrm{mg} \text { of freeze-dried sample; } 4 \mathrm{~mL} \text { ultra-pure water; } 12 \mathrm{~h} ; 4^{\circ} \mathrm{C} \text {. Potter homogenization for } 5 \mathrm{~min} ; 4^{\circ} \mathrm{C} \text {. Supernatant collected } \\
\text { after centrifugation }\left(15,000 \times g, 20 \mathrm{~min}, 44^{\circ} \mathrm{C}\right) \text {. } \\
\text { Alkaline treatment } \\
\text { Pellet resuspended in } 1 \mathrm{~mL} \text { of } 0.1 \mathrm{~N} \mathrm{NaOH} \text {; shaking occasionally for } 1 \mathrm{~h} \text {; room temperature. Supernatant collected after } \\
\text { centrifugation }(15,000 \times g, 20 \mathrm{~min} \text {, room temperature). }\end{array}$} & $\begin{array}{l}\text { Porphyra } \\
\text { acan- } \\
\text { thophora } \\
\text { var. acan- } \\
\text { thophora } \\
\text { Sargassum } \\
\text { vulgare }\end{array}$ & $11.5 \% \mathrm{dw}$ & $\begin{array}{l}8.9 \pm 0.7 \% \\
\mathrm{dw} \\
6.9 \pm 0.2 \% \\
\mathrm{dw}\end{array}$ & \multirow[t]{2}{*}{$\begin{array}{l}\text { Lowry } \\
\text { method }\end{array}$} & \multirow[t]{2}{*}{ [21] } \\
\hline & & & & $\begin{array}{c}\text { Ulva } \\
\text { fasciata }\end{array}$ & $12.8 \% \mathrm{dw}$ & $\begin{array}{l}7.3 \pm 0.8 \% \\
\mathrm{dw}\end{array}$ & & \\
\hline & \multirow{2}{*}{$\begin{array}{l}\text { Buffer treatment with } \\
\text { sonication }\end{array}$} & \multirow{2}{*}{ Tris- $\mathrm{HCl}$} & \multirow{2}{*}{$\begin{array}{l}10 \mathrm{~g} \text { of algal powder; } 200 \mathrm{~mL} \text { Tris- } \mathrm{HCl}(0.1 \mathrm{M} \mathrm{pH} 7.5) \text {; suspension submitted to ultrasound for } 1 \mathrm{~h} \text { (Ultrasonick } 300 \text { Ney, maximal } \\
\text { power); } 4^{\circ} \mathrm{C} \text {; stirred overnight. Supernatant collected after centrifugation }\left(10,000 \times \mathrm{g}, 20 \mathrm{~min}, 4^{\circ} \mathrm{C}\right) \text {. }\end{array}$} & Ulva rigida & $\begin{array}{l}112.0 \pm 5.8 \\
\mathrm{~g} \cdot \mathrm{kg}_{\mathrm{dw}}-1\end{array}$ & $\begin{array}{l}10.4 \pm \\
0.8 \% \\
\end{array}$ & \multirow{2}{*}{$\begin{array}{l}\text { Kjeldahl } \\
\text { method } \\
(\mathrm{N} \times 6.25)\end{array}$} & \multirow{2}{*}{ [84] } \\
\hline & & & & $\begin{array}{c}\text { Ulva } \\
\text { rotundata }\end{array}$ & $\begin{array}{l}100.1 \pm 4.9 \\
\mathrm{~g} \mathrm{~kg} \mathrm{dw}_{-1}\end{array}$ & $\begin{array}{l}16.1 \pm \\
0.9 \% \%^{\mathrm{a}}\end{array}$ & & \\
\hline
\end{tabular}


Table 3. Cont.

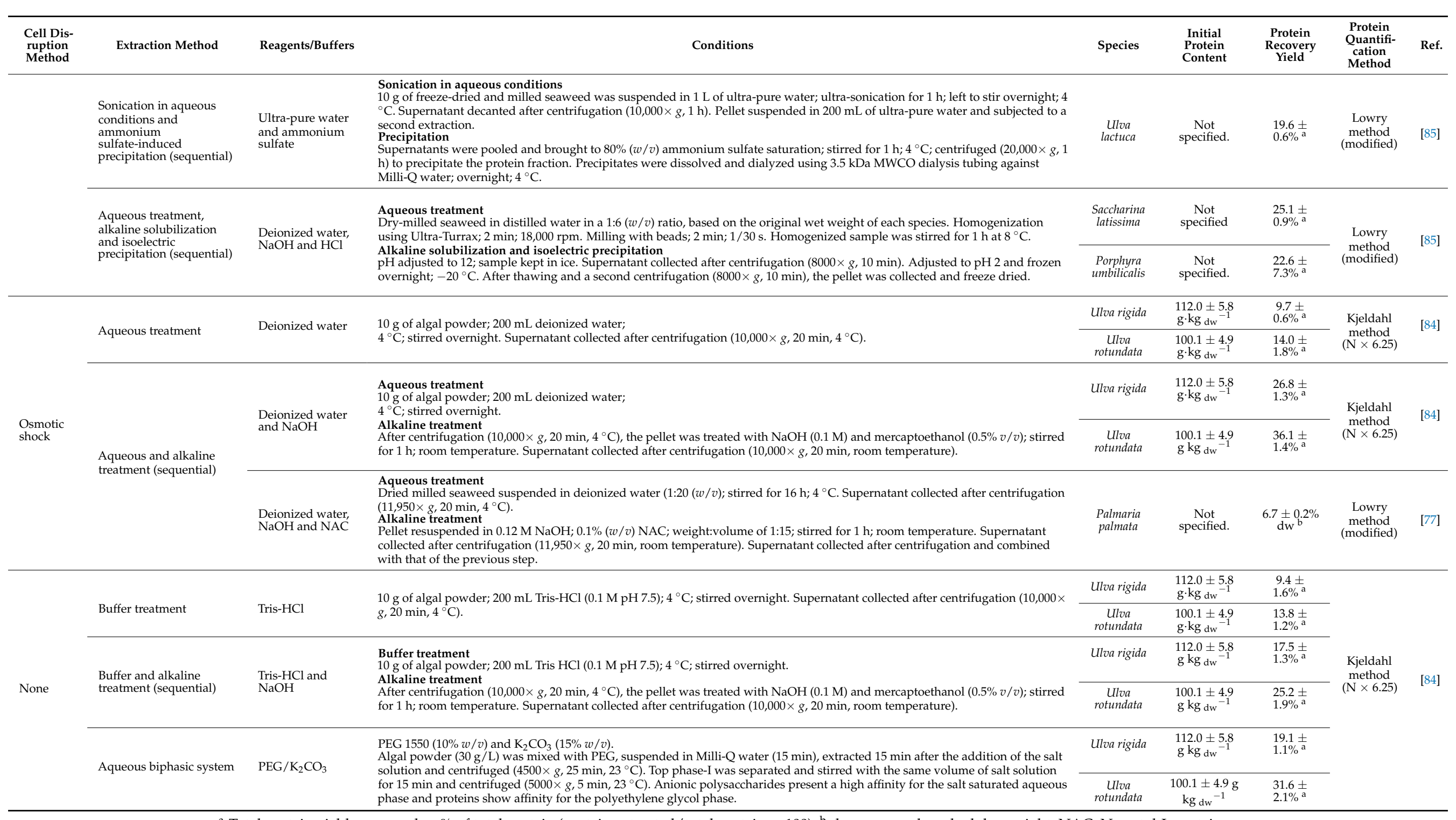

${ }^{a}$ Total protein yield expressed as $\%$ of total protein (protein extracted/total protein $\left.\times 100\right){ }^{b} \mathrm{dw}$ expressed as algal dry weight; NAC: N-acetyl-L-cysteine. 


\subsection{Novel Methods}

The design of a biorefinery usually follows a fractionation approach, so as to maximize the number, quality and quantity of the extractable products and thus enhance the value of the bioresource. This is why novel extraction methods are being sought; e.g., in seaweed, which might yield a more complete valorization of the macroalgae by obtaining pure extracts in the first separation steps and, concomitantly, not causing harm to the subsequently extracted components.

\subsubsection{Pulsed Electric Field Extraction}

Pulsed Electric Field Extraction (PEFE) is used as a cell disruption method, particularly in microalgae. It involves the application of short, high-voltage electric current pulses to perforate a cell wall or membrane. Depending on the intensity, amplitude, duration, number and repetition frequency of the external electric pulses, reversible or irreversible pores (electroporation) are formed in the membranes. Irreversible pore formation is of particular importance for extraction of bioactive compounds from natural matrices [14]. Treatments with an electric field strength from 0.7 to $3 \mathrm{kV} / \mathrm{cm}$, a specific energy of 1-20 kJ/kg, a couple of hundred of pulses and a total time duration lower than $1 \mathrm{~s}$ are usually used for natural products extraction [80]. When applied to $U$. lactuca, a higher protein content was observed, namely, $59 \mu \mathrm{g} \mathrm{mL}^{-1}$ against the $23 \mu \mathrm{g} \mathrm{mL} \mathrm{m}^{-1}$ obtained in the control [84]. When 50 pulses of $50 \mathrm{kV}$, applied at a $70.3 \mathrm{~mm}$ electrode gap, were used in the extraction of proteins from Ulva spp., a sevenfold increase in total protein content was obtained when compared to the use of osmotic shock [86]. The applied conditions can possibly limit the scale up of the method.

\subsubsection{Microwave-Assisted Extraction}

Microwave-Assisted Extraction (MAE) is another procedure used to enhance protein extraction from biological matrices. When microwave energy is transferred to the solution or suspension, the vibration/oscillation of the polar molecules occurs, causing inter- and intra-molecular friction. This effect combined with the movement and collision of a large number of charged particles leads to the heating of the matrices. Intracellular heating ultimately leads to pressurization effects that induce the breakdown of cell walls and membranes, in addition to electroporation effects [80]. Since MAE has been mostly used for analytical purposes (sample preparation), the results found in the literature focus on the reduction of extraction times rather than on its effects on parameters such as protein functionality [80].

This method can be carried out in open vessels (atmospheric pressure) or closed ones, under controlled pressure and temperature. In closed vessels, the solvent can be heated above its normal boiling point by manipulating the pressure, accelerating the mass transfer of the compounds from the natural matrix to the bulk solvent [87]. The higher the dielectric constant of the solvent and/or algal matrix, the greater the energy absorbed by the molecules and the faster the extraction temperature is reached [88,89], which makes polar solvents, such as water, the preferred choice.

\subsubsection{Pressurized Liquid Extraction}

Pressurized Liquid Extraction (PLE), or Accelerated Solvent Extraction (ASE), combines temperatures that range from 50 to $200^{\circ} \mathrm{C}$ and pressure ranging from 35 to $200 \mathrm{bar}$. These parameters are set for values lower than the solvent critical temperature and pressure, keeping it in its liquid state [20]. Both temperature and pressure increase the mass transfer rate. High pressures cause the solvent to reach temperatures higher than its normal boiling point and these higher temperatures enhance the solubility of the extractable components and reduce the viscosity and surface tension of the solvent [80]. Water is the most widely used solvent but other solvents, such as propane and dimethyl ether (DME), can also be 
used. Since DME is partially miscible with water, it allows the simultaneous extraction of non-polar target metabolites and the removal of water from wet matrices [90-92].

\subsubsection{Supercritical Fluid Extraction}

Supercritical Fluid Extraction (SFE) is an alternative extraction technique that produces extracts with very low contents of polar impurities [93]. It is a green technology, since a concentration step can most often be skipped after the extraction process [94]. A fluid becomes supercritical if subjected to temperature and pressure conditions above its critical point values $\left(\mathrm{P}_{\mathrm{c}} ; \mathrm{T}_{\mathrm{c}}\right)$. Experimental studies using SFE are usually limited to the region of $\mathrm{P}_{\mathrm{c}}<\mathrm{P} \leq 6 \mathrm{P}_{\mathrm{c}}$ and $\mathrm{T}_{\mathrm{c}}<\mathrm{T} \leq 1.4 \mathrm{~T}_{\mathrm{c}}$ [95]. Under supercritical conditions, some of the properties of the fluid become indistinguishable from those of its gaseous state, with a density similar to that of a liquid, but with diffusivity and viscosity matching those of a gas. This makes supercritical fluids capable of a faster and deeper penetration into the solid particles of the matrix to be processed [93]. The fluid must be chosen carefully, especially when dealing with thermolabile compounds. Carbon dioxide, with $\mathrm{T}_{\mathrm{C}}$ and $\mathrm{P}_{\mathrm{C}}$ values of $31.1{ }^{\circ} \mathrm{C}$ and 73.9 bar, is by far the most used supercritical solvent [96]. In addition to being ideal for the extraction of thermolabile compounds, it has low viscosity, low surface tension, high diffusivity, is non-toxic, non-flammable, widely available and chemically inert under the conditions relevant for the extraction process. The fact that it is gaseous at normal pressure and temperature eliminates the need for a solvent evaporation step after extraction [96]. The greatest limitation of supercritical $\mathrm{CO}_{2}$ is that it is not suitable for extraction of polar compounds [97].

The addition of an organic modifier, such as ethanol or methanol, can greatly improve the extraction efficiency with supercritical $\mathrm{CO}_{2}$ [96]. Other possible supercritical solvents, such as water, methanol, ethanol, acetone, chloroform, ethyl acetate and toluene, are usually avoided when extracting bioactive compounds, since their $\mathrm{T}_{\mathrm{c}}$ value is above $200{ }^{\circ} \mathrm{C}$ [80].

The SFE technology has been used for processing seaweeds and other plant-based materials mainly to extract non-polar and small-size molecular components, such as pigments (chlorophylls, carotenoids) and some lipids (e.g., sterols) that are valuable as food and pharmaceutical ingredients. Proteins, polysaccharides, long-chain fatty acids and phlorotannins have also been recovered from seaweeds under PLE using subcritical solvents, and/or subcritical water and organic modifiers (SWE) [98]. Therefore, SFE may be a first processing step in seaweed biorefinery strategy [85] wherein the protein extraction step, from the first-extracted biomass, could be done either by PLE, SWE or conventional methods, after optimizing the operating conditions to increase the selectivity, as recommended for biorefineries of other plant-based resources [98].

\subsubsection{Switchable or Smart Solvents}

Switchable solvents are a new class of smart extraction solvents that can switch from a non-ionic form to an ionic liquid through contact with $\mathrm{CO}_{2}$ gas bubbles. Exposure to $\mathrm{N}_{2}$ allows them to return to their non-ionic form [14]. Ionic liquids (ILs) are composed of large asymmetric organic cations (imidazolium, pyrrolidinium, pyridinium, ammonium or phosphonium) and different inorganic or organic anions, such as $\mathrm{BF}^{4-}, \mathrm{PF}^{6-}, \mathrm{Cl}^{-}$ and $\mathrm{Br}^{-}$[80]. They are very versatile, since their polarity, hydrophobicity, viscosity and other properties highly depend on the cationic or anionic constituents selected, hence being referred to as "designer solvents". They have low melting points (below $100{ }^{\circ} \mathrm{C}$ ) and their non-flammable and non-volatile nature makes them an attractive choice for the development of safer processes [80].

The basis of the extraction mechanism with ILs lies in their interaction with macroalgal cell walls. As mentioned, cellulose is a core component of algae cell walls, although its proportion varies between species. The use of a solvent capable of disrupting the intermolecular H-bond interactions leads to cellulose dissolution [99]. Indeed, several ILs have been found to dissolve large amounts of cellulose [100]. These interactions are relevant because they ultimately lead to the complete or partial disruption of cell walls [101]. 


\section{Protein Enrichment Methods}

Using seaweed as a protein resource requires the processing of biomass to deliver a concentrated form of high-quality protein. The protein concentration from plant materials has traditionally been achieved directly by extracting and isolating the protein, or indirectly by extracting the non-protein components. In contrast with other plant materials, isolating and concentrating proteins from seaweed is a relatively unexplored domain and most protocols tend to focus solely on the initial extraction methods [102]. Purification of the extracted proteins represents a challenge, especially for novel proteins because of their unknown physicochemical properties. The selection of the method also depends on the final application of the product and the scale of production. The extraction method used also influences the purification method chosen. For example, reducing agents, such as $\mathrm{N}$-acetyl-L-cysteine, which are used to improve cell wall-associated protein extraction, might have to be avoided, depending on the applications of the extracted proteins.

Single or combined enrichment methods can be employed. These methods include precipitation, membrane technologies and chromatography [14]. A combination of membrane technologies could be used to isolate seaweed proteins using the same principles used to obtain protein isolates in the dairy industry. Microfiltration (MF) could be used to remove the cell wall components, ultrafiltration (UF) could be used to isolate proteins with a molecular weight between 1 and $200 \mathrm{kDa}$, nanofiltration (NF) could be used to remove monovalent salts and reverse osmosis (RO) to reduce the final volume [103]. Ultrafiltration has been applied after supercritical $\mathrm{CO}_{2}$ and ultrasonic-assisted extraction to isolate polysaccharides from Sargassum pallidum [25] and after hot water extraction in Ulva fasciata [104]. Most protocols reported in the literature often describe methods for the purification and isolation of specific proteins, namely, R-PE. Some examples are presented in Table 4.

Table 4. Examples of proteins from algae species and the methods tested for their purification.

\begin{tabular}{|c|c|c|c|c|c|c|}
\hline Aim & $\begin{array}{l}\text { Extraction } \\
\text { Method }\end{array}$ & $\begin{array}{l}\text { Enrichment } \\
\text { Method }\end{array}$ & Conditions & Species & Results & Ref. \\
\hline $\begin{array}{l}\text { Concentrate } \\
\text { R-PE; } \\
\text { pre-purify by } \\
\text { eliminating } \\
\text { proteins other } \\
\text { than R-PE and } \\
\text { polysaccha- } \\
\text { rides. }\end{array}$ & $\begin{array}{l}\text { Centrifugation } \\
\text { of algal powder } \\
\text { after } \\
\text { suspension in } \\
\text { distilled water. }\end{array}$ & Ultrafiltration & $\begin{array}{l}\text { PES membrane; MWCO of } \\
25-30 \mathrm{kDa} \text {; surface area of } \\
0.033 \mathrm{~m}^{2} ; 20{ }^{\circ} \mathrm{C} ; 4 \text { bar; } \\
\text { volumetric concentration } \\
\text { factor of } 5 .\end{array}$ & $\begin{array}{c}\text { Grateloupia } \\
\text { turuturu }\end{array}$ & $\begin{array}{l}100 \% \text { of R-PE } \\
\text { recovered; } \\
32.9 \% \text { of other } \\
\text { proteins and } \\
64.6 \% \text { of sugars } \\
\text { passed through } \\
\text { the membrane. }\end{array}$ & [105] \\
\hline $\begin{array}{l}\text { Concentrate } \\
\text { phycobilipro- } \\
\text { teins (R-PE and } \\
\text { allophyco- } \\
\text { cyanin). }\end{array}$ & $\begin{array}{l}\text { Mixing of algal } \\
\text { powder in } 50 \\
\text { mM citrate } \\
\text { buffer (pH 6) } \\
\text { for } 24 \mathrm{~h} \text { and } \\
\text { centrifugation } \\
\text { of the } \\
\text { suspension. }\end{array}$ & $\begin{array}{l}\text { Microfiltration; } \\
\text { Ultrafiltration } \\
\text { and SEC }\end{array}$ & $\begin{array}{c}\text { Microfiltration and } \\
\text { Ultrafiltration } \\
\text { membranes of RC, } 0.45 \mu \mathrm{m} \text {, } \\
\text { and of PES, } 50 \mathrm{kDa} \text { of } \mathrm{MWCO} \text {. } \\
\text { SEC } \\
\text { Mobile phase: Phosphate } \\
\text { buffer (pH } 7.2,50 \mathrm{mM} \text { sodium } \\
\text { phosphate and } 150 \mathrm{mM} \mathrm{NaCl} \text { ); } \\
\text { room temperature. Stationary } \\
\text { phase with } 34 \mu \mathrm{m} \text { average } \\
\text { particle size. }\end{array}$ & $\begin{array}{l}\text { Furcellaria } \\
\text { lumbricalis }\end{array}$ & $\begin{array}{l}60-75 \% \text { of R-PE } \\
\text { and allophyco- } \\
\text { cyanin were } \\
\text { recovered } \\
\text { values } \\
\text { dependent on } \\
\text { the detector, } \\
\text { (fluorescence or } \\
\text { photodiode } \\
\text { array). }\end{array}$ & [106] \\
\hline
\end{tabular}


Table 4. Cont.

\begin{tabular}{|c|c|c|c|c|c|c|}
\hline Aim & $\begin{array}{l}\text { Extraction } \\
\text { Method }\end{array}$ & $\begin{array}{l}\text { Enrichment } \\
\text { Method }\end{array}$ & Conditions & Species & Results & Ref. \\
\hline Isolate R-PE. & $\begin{array}{l}\text { Mixing of fresh } \\
\text { thallus in } \\
\text { phosphate } \\
\text { buffer }(0.02 \\
\text { mM; pH 7.2); } \\
\text { pulverization of } \\
\text { the mixture. }\end{array}$ & $\begin{array}{l}\text { Isoelectric } \\
\text { Precipitation } \\
\text { and AEX }\end{array}$ & $\begin{array}{l}\text { Filtration (gauze); repeated } \\
\text { freezing and thawing; } \\
\text { centrifugation; supernatant } \\
\text { precipitation with } 35 \% \\
\text { saturated ammonium sulfate; } \\
\text { supernatant precipitation with } \\
55 \% \text { saturated ammonium } \\
\text { sulfate; centrifugation; dialysis } \\
\text { against } 50 \mathrm{mM} \text { phosphate } \\
\text { buffer (pH 7.2). } \\
\text { Q-Sepharose column; flow rate } \\
\text { of } 2.0 \text { mL/min; elution with } 50 \\
\text { mM phosphate buffer (pH } 7.2) \\
\text { with an increasing gradient of } \\
\text { NaCl (0 to } 200 \mathrm{mM} \text { ); elution of } \\
\text { the active fraction occurs at a } \\
\text { concentration of NaCl of } \\
200 \mathrm{mM} \text {. }\end{array}$ & $\begin{array}{c}\text { Portieria } \\
\text { hornemannii }\end{array}$ & $\begin{array}{l}\text { R-PE recovery } \\
\text { of } 64.8 \% \text { with } \\
\text { purity of } 5.2 \% \text {. }\end{array}$ & [107] \\
\hline Isolate R-PE. & $\begin{array}{c}\text { Dried algal } \\
\text { hydration with } \\
\text { deionized water } \\
\text { overnight; } \\
\text { slurry filtration } \\
\text { through gauze. }\end{array}$ & $\begin{array}{c}\text { Supernatant } \\
\text { precipitation } \\
\text { with } \\
\text { ammonium } \\
\text { sulfate (final } \\
\text { concentration } \\
\text { of } 0.5 \mathrm{M} \text { ). EBA } \\
\text { and AEX. }\end{array}$ & $\begin{array}{l}\text { EBA-Streamline } \mathrm{T}^{\mathrm{TM}} \text { column; } \\
\text { supernatant injected with the } \\
\text { crude extracts; eluates pooled } \\
\text { and dialyzed against distilled } \\
\text { water overnight at } 4{ }^{\circ} \mathrm{C} \text {. } \\
\text { AEX-DEAE-Sepharose } \\
\text { column; flow rate of } \\
2.5 \mathrm{~mL} / \mathrm{min} \text {; sodium acetate } \\
\text { (NaAc) buffer ( } 4 \mathrm{mM} \text {; } \mathrm{pH} 4.5 \text { ) } \\
\text { eliminates phycocyanin } \\
\text { contaminants; } 1 \mathrm{mM} \text { NaAc } \\
\text { buffer (pH } 4.5 \text { ) and phosphate } \\
\text { buffer (50 mM; pH } 6.8 \text { ) } \\
\text { eliminates other contaminant } \\
\text { proteins; elution with } \\
\text { phosphate buffer ( } 30 \mathrm{mM} \text {; } \\
\text { pH 6.8) using an increasing } \\
\text { gradient of } \mathrm{NaCl} \text { from } \\
0 \text { to } 200 \mathrm{mM} \text {. }\end{array}$ & $\begin{array}{l}\text { Gracilaria le- } \\
\text { maneiformis }\end{array}$ & $\begin{array}{c}\text { R-PE recovery } \\
\text { of } 21 \% \text { with } \\
\text { purity ratio } \\
>3.2 .\end{array}$ & [108] \\
\hline
\end{tabular}

AEX—anion-exchange chromatography; EBA—expanded bed adsorption; MWCO—molecular weight cut-off; PES—polyethersulfone; RC—regenerated cellulose; SEC—size-exclusion chromatography.

\section{Protein Characterization Methods}

Characterization and/or identification of isolated proteins is usually carried out by direct comparison with standard molecules and/or data collected from the available literature. This approach is successful until unknown compounds are brought into consideration for which standards are not available [14]. Exploratory methods thus have to be used.

\subsection{SDS-PAGE}

Sodium dodecyl sulfate polyacrylamide gel electrophoresis (SDS-PAGE) is used to identify the molecular weight of dominant protein subunits bands (Table 5). This method has been used to identify the protein profiles of different seaweeds, such as Ulva spp. [28], Gracilaria changii [109], Caulerpa lentillifera, Caulerpa racemose and Kappaphycus spp., amongst others [110]. 
Table 5. Protein isolation and characterization using SDS-PAGE methods in different seaweed species.

\begin{tabular}{|c|c|c|c|c|}
\hline Species & Identified Proteins & Molecular weight & Method & Ref. \\
\hline Eisenia bicyclis & $\begin{array}{l}\text { EHEP (Eisenia } \\
\text { hydrolysis enhancing } \\
\text { protein) }\end{array}$ & $25 \mathrm{kDa}$ & SDS-PAGE and 2D-PAGE & [111] \\
\hline $\begin{array}{l}\text { Furcellaria } \\
\text { lumbricalis }\end{array}$ & R-PE & $\sim 25 \mathrm{kDa}$ & $\begin{array}{l}\text { SDS-PAGE using 4-15\% Mini-Protean }{ }^{\circledR} \\
\text { TGX Stain Free Precast Gel. }\end{array}$ & [106] \\
\hline $\begin{array}{l}\text { Himantalia } \\
\text { elongata }\end{array}$ & 5 proteins & $\begin{array}{c}71.6,53.7,43.3,36.4 \\
27.1 \mathrm{kDa}\end{array}$ & $\begin{array}{l}\text { Tris-Tricine-SDS-PAGE using 10-20\% } \\
\text { Mini-Protean }{ }^{\circledR} \text { Tris-Tricine Precast Gel. }\end{array}$ & [112] \\
\hline Laminaria japonica & $\begin{array}{l}\text { LJGP (Laminaria } \\
\text { japonica novel } \\
\text { glycoprotein) }\end{array}$ & $\sim 10 \mathrm{kDa}$ & $\begin{array}{l}\text { SDS-PAGE on } 15 \% \text { gels; periodic } \\
\text { acid-Schiff staining for glycoprotein } \\
\text { bands. }\end{array}$ & [113] \\
\hline Palmaria palmata & $\begin{array}{l}\text { One prominent area of } \\
\text { staining (suspected of } \\
\text { being subunits of } \\
\text { phycoerythrin or other } \\
\text { phycobiliproteins). }\end{array}$ & $\sim 20 \mathrm{kDa}$ & $\begin{array}{l}\text { SDS-PAGE using a Mini-Protean }{ }^{\circledR} \mathrm{II} \\
\text { electrophoresis system with } 4 \mathrm{~g} / 100 \mathrm{~mL} \\
\text { acrylamide stacking gel and } 12.5 \mathrm{~g} / 100 \\
\text { mL acrylamide resolving gel. }\end{array}$ & [77] \\
\hline Pyropia yezoensis & $\begin{array}{l}2 \text { proteins: PYP1 and } \\
\text { PYP2 (Pyropia yezoensis } \\
\text { porphyran } 1 \text { and } 2) .\end{array}$ & $\begin{array}{l}\text { PYP1: } 10 \mathrm{kDa}, \\
\text { SDS-resistant dimer; } \\
\text { PYP2: } 10 \mathrm{kDa} .\end{array}$ & SDS-PAGE using a $18 \%$ acrylamide gel. & [114] \\
\hline
\end{tabular}

\subsection{Chromatography}

As mentioned in Section 3, chromatographic methods are widely used for separation and purification of seaweed proteins and they can be used also for their characterization. High-Performance Liquid Chromatography (HPLC) is often used coupled with other chromatographic methods, such as Size-Exclusion Chromatography (HPSEC) [106]. Amino acid profiles after protein digestion can be analyzed with gaseous or liquid chromatography (GC or LC) with a derivatization step, which includes treatment with ortho-phtalaldehyde (OPA) or fluorenylmethoxy chloroformate (FMOC) $[115,116]$. However, assessment of the amino acid profile without derivatization by using anion exchange chromatography (HPAEC-PAD) has been reported [117]. Examples of chromatographic methods used for seaweed protein isolation and characterization are shown in Table 6.

Table 6. Protein isolation and characterization using chromatographic methods in different seaweed species.

\begin{tabular}{|c|c|c|c|c|}
\hline Species & Identified Proteins & Molecular Weight & Method & Ref. \\
\hline Ascophyllum nodosum & Protein profile & From 2.6 to $3.8 \mathrm{kDa}$ & $\begin{array}{l}\text { HPLC and SEC (HPSEC); } \\
\text { macroporous HPLC column } \\
\text { with particle size of } 4-6 \mu \mathrm{m} \\
\text { and pore size of } 150-300 \AA\end{array}$ & [106] \\
\hline $\begin{array}{l}\text { Saccharina } \\
\text { latissima }\end{array}$ & $\begin{array}{l}\text { Trypanothione reductase and } \\
\text { ATP synthase subunit beta } \\
\text { (chloroplastic); actin-1; } \\
\text { elongation factor Tu; } \\
\text { glyceraldehyde-3-phosphate } \\
\text { dehydrogenase. }\end{array}$ & $\begin{array}{c}51,41,40,39 \mathrm{kDa} \\
\text { (respectively) }\end{array}$ & $\begin{array}{l}\text { HPSEC and SDS-PAGE; } 4-20 \% \\
\text { Precast Mini-Protean }{ }^{\circledR} \text { linear } \\
\text { gel; two serially connected } \\
\text { columns-1st with } 5 \mu \mathrm{m} \\
\text { particle size, } 150 \AA \text { pore size, } \\
\text { 2nd with } 5 \mu \mathrm{m} \text { particle size } \\
\text { and } 300 \AA \text { pore size. }\end{array}$ & [118] \\
\hline
\end{tabular}

\subsection{Spectrometry}

Fourier Transform Infrared (FTIR) spectroscopy is used to obtain information about the structural composition of proteins, especially when it comes to their secondary structural conformation [27]. Mass spectrometry (MS) can be an accurate protein identification tool and electrospray ionization (ESI) and matrix-assisted laser desorption ionizations/time- 
of-flight (MALDI-TOF) can also be important tools [27]. Examples of their application to seaweed proteins are shown in Table 7.

Table 7. Protein characterization using spectrometry methods in different seaweed species.

\begin{tabular}{|c|c|c|c|}
\hline Species & $\begin{array}{l}\text { Structural Features Searched } \\
\text { and Respective Bands, or } \\
\text { Identified Proteins/Peptides }\end{array}$ & Method & Ref. \\
\hline Codium fragile & Codiase & $\begin{array}{l}\text { Fibrin(ogen)olytic activity of codiase was } \\
\text { examined by FTIR spectroscopy and the } \\
\text { molecular weight of codiase was determined by } \\
\text { MALDI-TOF mass spectrometry in linear mode. }\end{array}$ & [40] \\
\hline Kappaphycus alvarezzi & $\begin{array}{l}704 \mathrm{~cm}^{-1}: \mathrm{N}-\mathrm{H} \text { bending. } \\
616 \mathrm{~cm}^{-1}: \text { phosphate group. }\end{array}$ & $\begin{array}{c}\text { The lyophilized protein concentrate was } \\
\text { pelletized with potassium bromide }(1 / 100 \text { ratio } \\
w / w) \text { and the spectral analysis was carried out } \\
\text { using FTIR. }\end{array}$ & [119] \\
\hline $\begin{array}{l}\text { Macrocystis pyrifera and } \\
\text { Chondracanthus chamissoi }\end{array}$ & $\begin{array}{l}3281 \mathrm{~cm}^{-1} \text { and } 3274 \mathrm{~cm}^{-1}: \mathrm{N}-\mathrm{H} \\
\text { vibrations. } \\
1637 \mathrm{~cm}^{-1} \text { and } 1544 \mathrm{~cm}^{-1}: \mathrm{C}=\mathrm{O} \\
\text { vibrations. } \\
1220 \mathrm{~cm}^{-1} \text { and } 1243 \mathrm{~cm}^{-1}: \mathrm{S}=\mathrm{O} \\
\text { vibrations. }\end{array}$ & $\begin{array}{l}\text { FTIR of dried seaweed and protein extracts } \\
\text { of seaweeds. }\end{array}$ & [75] \\
\hline $\begin{array}{l}\text { Palmaria palmata and } \\
\text { Soliera chordalis }\end{array}$ & Bioactive peptides & $\begin{array}{l}\text { Peptide samples were separated by online } \\
\text { reversed-phase (RP) nanoscale capillary liquid } \\
\text { chromatography (nanoLC) and analyzed by } \\
\text { electrospray mass spectrometry (ES MS/MS). }\end{array}$ & [49] \\
\hline $\begin{array}{l}\text { Palmaria palmata, Palmaria } \\
\text { umbilicalis, Ulva rigida, } \\
\text { Ulva pinnatifida and } \\
\text { Laminaria zchroleuca }\end{array}$ & $\begin{array}{l}\text { Mono-iodotyrosine } \\
\text { and diiodotyrosine }\end{array}$ & $\begin{array}{l}\text { Reverse phase high performance liquid } \\
\text { chromatography (RP-HPLC) with inductively } \\
\text { coupled plasma mass spectrometry (ICP-MS). }\end{array}$ & [120] \\
\hline
\end{tabular}

\section{Conclusions}

Given the current interest in sustainable protein sources, macroalgae have been identified as promising alternatives due to their protein quality and bioactivities. Seaweed proteins and seaweed-derived proteins are still poorly explored, and the development of appropriate and feasible extraction and purification processes is of growing interest in order to incorporate them in pharmaceutical, nutraceutical, cosmeceutical or food and feed applications. The major identified challenges lie on improving the protein yield and on the disruption of the polysaccharide-rich cell wall. Cell disruption techniques play indeed an essential role in the successful extraction and enrichment of algal protein at larger scales. Additionally, the protein contents and quality highly depend on parameters such as the species, harvesting season, location and growing conditions.

Conventional protein extraction methods, such as enzymatic hydrolysis and various physical processes, are laborious, time-consuming and costly, and may require the use of solvents. Novel methods, such as PEF, MAE, PLE and SFE, have been predominantly used in the extraction of compounds other than proteins, and are still poorly explored in algae. Table 8 briefly compares relevant aspects of these conventional and novel extraction methods. 
Table 8. Comparison of the relevant aspects of protein extraction methods.

\begin{tabular}{|c|c|c|c|}
\hline Aim/Method & Main Advantages & Main Drawbacks & Ease of Scale-Up ** \\
\hline \multicolumn{4}{|l|}{ Cell wall disruption } \\
\hline Osmotic shock & Low energy; selectivity & Cost of chemicals; diluted product & +++ \\
\hline Mechanical shearing & No chemicals; high yield & Energy cost; heat damage * & +++ \\
\hline Enzyme treatment (EAE) & Low energy; selectivity & $\begin{array}{l}\text { Cost of enzymes; product } \\
\text { contaminated with enzyme }\end{array}$ & ++ \\
\hline Ultrasonication (UAE) & No chemicals; high yield & $\begin{array}{l}\text { Energy cost; heat damage *; } \\
\text { equipment cost }\end{array}$ & ++ \\
\hline Pulsed electric field (PEFE) & No chemicals; high yield & $\begin{array}{l}\text { Energy cost; heat damage *; } \\
\text { equipment cost }\end{array}$ & + \\
\hline Microwave (MAE) & No chemicals; high yield & $\begin{array}{l}\text { Energy cost; heat damage *; } \\
\text { equipment cost }\end{array}$ & + \\
\hline \multicolumn{4}{|l|}{ Protein extraction } \\
\hline $\begin{array}{l}\text { Aqueous solubilization (water, } \\
\text { alkali, buffer) }\end{array}$ & $\begin{array}{c}\text { Mild conditions; } \\
\text { bioactivity preserved }\end{array}$ & $\begin{array}{c}\text { Limited recovery yield; } \\
\text { diluted product }\end{array}$ & +++ \\
\hline Aqueous biphasic systems & $\begin{array}{l}\text { Mild conditions; bioactivity } \\
\text { preserved; achievable high } \\
\text { recovery yield and selectivity; }\end{array}$ & $\begin{array}{c}\text { Cost of chemicals; improvements } \\
\text { depend on cost and } \\
\text { environmental impact }\end{array}$ & ++ \\
\hline $\begin{array}{l}\text { Pressurized liquid extraction } \\
\text { (PLE)/ Accelerated solvent } \\
\text { extraction (ASE) }\end{array}$ & Higher recovery yield & $\begin{array}{l}\text { Energy cost; heat damage *; } \\
\text { equipment cost; possible product } \\
\text { contamination by co-solvents }\end{array}$ & ++ \\
\hline $\begin{array}{l}\text { Enzymatic protein } \\
\text { hydrolysis (EAE) }\end{array}$ & $\begin{array}{l}\text { Higher recovery yield; tailored } \\
\text { protein modification; possible } \\
\text { gain of peptide bioactivities }\end{array}$ & $\begin{array}{l}\text { Cost of enzymes; loss of protein } \\
\text { bioactivity/function }\end{array}$ & ++ \\
\hline \multicolumn{4}{|l|}{ Protein enrichment } \\
\hline Precipitation & $\begin{array}{l}\text { High recovery yield; } \\
\text { mild conditions }\end{array}$ & Cost of chemicals; low selectivity & +++ \\
\hline $\begin{array}{c}\text { Membrane separation (MF, UF, } \\
\text { NF, RO) }\end{array}$ & $\begin{array}{l}\text { High recovery yield; no chemicals; } \\
\text { mild conditions }\end{array}$ & $\begin{array}{l}\text { Cost of membranes; } \\
\text { low selectivity }\end{array}$ & +++ \\
\hline Adsorption/Chromatography & $\begin{array}{l}\text { High selectivity; high } \\
\text { recovery yield }\end{array}$ & $\begin{array}{l}\text { Cost of adsorber media, } \\
\text { instrumentation and } \\
\text { buffer chemicals }\end{array}$ & ++ \\
\hline $\begin{array}{l}\text { Supercritical fluid } \\
\text { extraction (SFE) }\end{array}$ & $\begin{array}{l}\text { High selectivity for low } \\
\text { polarity impurities }\end{array}$ & $\begin{array}{l}\text { Energy cost; equipment cost; } \\
\text { possible product contamination } \\
\text { by co-solvents }\end{array}$ & + \\
\hline
\end{tabular}

${ }^{*}$ Need of thermal control. ${ }^{* *}$ From + (minimum) to $+++($ maximum $)$.

To achieve progress in this protein extraction area, future work addressing the applicability of these novel methods is necessary. The same applies to membrane technologies, which also show great promise to pre-purify/concentrate or even isolate (in membrane chromatography) compounds, but are still fully underexploited regarding the protein extraction from macroalgae.

Author Contributions: Conceptualization, M.M. and M.T.C.; investigation, M.G., M.M. and M.T.C.; writing—original draft preparation, M.G.; writing—review and editing, H.M.P., M.M., M.M.R.d.F. and M.T.C.; project administration, H.M.P. and M.T.C.; funding acquisition, M.M.R.d.F. and M.T.C. All authors have read and agreed to the published version of the manuscript.

Funding: This research was funded by Fundo Azul—Direcção-Geral de Política do Mar, Ministério do Mar, Portugal, grant number FA_05_2017_033. Funding received by national funds from FCTFundação para a Ciência e a Tecnologia, I.P., in the scope of the project UIDB/04565/2020 and $\mathrm{UIDP} / 04565 / 2020$ of the Research Unit Institute for Bioengineering and Biosciences-iBB and the project LA/P/0140/2020 of the Associate Laboratory Institute for Health and Bioeconomy-i4HB is acknowledged. 
Acknowledgments: Work developed within the scope of the Smart Valorization of Macroalgae project with the support of IBERAGAR S.A., SPAROS Ltd and IPMA.

Conflicts of Interest: The authors declare no conflict of interest. The funders had no role in the design of the study; in the collection, analyses, or interpretation of data; in the writing of the manuscript, or in the decision to publish the results.

\section{References}

1. IEA Bioenergy Task 42 Biorefining. Available online: https://task42.ieabioenergy.com/ (accessed on 20 August 2021).

2. Stengel, D.B.; Connan, S. Marine Algae: A Source of Biomass for Biotechnological Applications. In Natural Products from Marine Algae; Humana Press: New York, NY, USA, 2015; Volume 1308, pp. 1-37. [CrossRef]

3. Chojnacka, K.; Wieczorek, P.; Schroeder, G.; Michalak, I. Algae Biomass: Characteristics and Applications, 8th ed.; Springer International Publishing: Cham, Switzerland, 2018. [CrossRef]

4. Bold, H.; Wynne, M. Introduction to the Algae: Structure and Reproduction; Prentice-Hall: Englewood Cliffs, NJ, USA, 1978.

5. Lobban, C.; Wynne, M. The Biology of Seaweeds; University of California Press: Berkeley, CA, USA, 1981.

6. Van den Hoek, C.; Mann, D.; Jahns, H. Algae: An Introduction to Phycology; Cambridge University Press: Berkeley, CA, USA, 1995. [CrossRef]

7. Reed, R.; Lobban, C.; Harrison, P.; Duncan, M. The Physiological Ecology of Seaweeds. J. Ecol. 1986, 74, 611. [CrossRef]

8. Santelices, B. Production Ecology of Gelidium. Hydrobiologia 1991, 221, 31-44. [CrossRef]

9. Gao, K.; McKinley, K.R. Use of Macroalgae for Marine Biomass Production and $\mathrm{CO}_{2}$ Remediation: A Review. J. Appl. Phycol. 1994, 6, 45-60. [CrossRef]

10. Percival, E.; McDowell, R. Algal Polysaccharides. In Methods in Plant Biochemistry; Academic Press: Cambridge, MA, USA, 1990; Volume 2, pp. 523-547. [CrossRef]

11. Cesário, M.T.; da Fonseca, M.M.R.; Marques, M.M.; de Almeida, M.C.M.D. Marine Algal Carbohydrates as Carbon Sources for the Production of Biochemicals and Biomaterials. Biotechnol. Adv. 2018, 36, 798-817. [CrossRef] [PubMed]

12. Lahaye, M.; Robic, A. Structure and Function Properties of Ulvan, a Polysaccharide from Green Seaweeds. Biomacromolecules 2007, 8, 1765-1774. [CrossRef] [PubMed]

13. McHugh, D. A Guide to the Seaweed Industry; Food and Agriculture Organization of the United States: Rome, Italy, 2003.

14. Pliego-Cortés, H.; Wijesekara, I.; Lang, M.; Bourgougnon, N.; Bedoux, G. Current Knowledge and Challenges in Extraction, Characterization and Bioactivity of Seaweed Protein and Seaweed-Derived Proteins. Adv. Bot. Res. 2020, 95, 289-326. [CrossRef]

15. Fleurence, J. Seaweed Proteins. In Proteins in Food Processing; Elsevier Ltd.: Amsterdam, The Netherlands, 2004; pp. 197-213. [CrossRef]

16. Sánchez-Machado, D.; López-Cervantes, J.; López-Hernández, J.; Paseiro-Losada, P. Fatty Acids, Total Lipid, Protein and Ash Contents of Processed Edible Seaweeds. Food Chem. 2004, 85, 439-444. [CrossRef]

17. Biris-Dorhoi, E.S.; Michiu, D.; Pop, C.; Rotar, A.; Tofana, M.; Pop, O.; Socaci, S.; Farcas, A. Macroalgae-A Sustainable Source of Chemical Compounds with Biological Activities. Nutrients 2020, 12, 3085. [CrossRef] [PubMed]

18. Pimentel, F.; Alves, R.; Harnedy, P.; FitzGerald, R.; Oliveira, M. Macroalgal-Derived Protein Hydrolysates and Bioactive Peptides: Enzymatic Release and Potential Health Enhancing Properties. Trends Food Sci. Technol. 2019, 93, 106-124. [CrossRef]

19. Marsham, S.; Scott, G.; Tobin, M. Comparison of Nutritive Chemistry of a Range of Temperate Seaweeds. Food Chem. 2007, 4, 1331-1336. [CrossRef]

20. Day, L. Proteins from Land Plants-Potential Resources for Human Nutrition and Food Security. Trends Food Sci. Technol. 2013, 32, 25-42. [CrossRef]

21. Barbarino, E.; Lourenço, S. An Evaluation of Methods for Extraction and Quantification of Protein from Marine Macro-and Microalgae. J. Appl. Phycol. 2005, 17, 447-460. [CrossRef]

22. Machado, M.; Machado, S.; Pimentel, F.; Freitas, V.; Alves, R.; Oliveira, M. Amino Acid Profile and Protein Quality Assessment of Macroalgae Produced in an Integrated Multi-Trophic Aquaculture System. Foods 2020, 9, 1382. [CrossRef]

23. Cian, R.; Drago, S.; de Medina, F.; Martínez-Augustin, O. Proteins and Carbohydrates from Red Seaweeds: Evidence for Beneficial Effects on Gut Function and Microbiota. Mar. Drugs 2015, 13, 5358-5383. [CrossRef]

24. Mittal, R.; Sharma, R.; Raghavarao, K. Aqueous Two-Phase Extraction of R-Phycoerythrin from Marine Macro-Algae, Gelidium pusillum. Bioresour. Technol. 2019, 280, 277-286. [CrossRef]

25. Denis, C.; Massé, A.; Fleurence, J.; Jaouen, P. Concentration and Pre-Purification with Ultrafiltration of a R-Phycoerythrin Solution Extracted from Macro-Algae Grateloupia turuturu: Process Definition and up-Scaling. Sep. Purif. Technol. 2009, 69, 37-42. [CrossRef]

26. Le Guillard, C.; Dumay, J.; Donnay-Moreno, C.; Bruzac, S. Ultrasound-Assisted Extraction of R-Phycoerythrin from Grateloupia turuturu with and without Enzyme Addition. Algal Res. 2015, 12, 522-528. [CrossRef]

27. Pliego-Cortés, H.; Caamal-Fuentes, E.; Montero-Muñoz, J.; Freile-Pelegrín, Y.; Robledo, D. Growth, Biochemical and Antioxidant Content of Rhodymenia pseudopalmata (Rhodymeniales, Rhodophyta) Cultivated under Salinity and Irradiance Treatments. J. Appl. Phycol. 2017, 29, 2595-2603. [CrossRef]

28. Wijesekara, I.; Lang, M.; Marty, C.; Gemin, M. Different Extraction Procedures and Analysis of Protein from Ulva sp. in Brittany, France. J. Appl. Phycol. 2017, 29, 2503-2511. [CrossRef] 
29. Abdel-fattah, A.; Sary, H.H. Glycoproteins from Ulva lactuca. Phytochemistry 1987, 26, 1447-1448. [CrossRef]

30. Yoshiie, T.; Maeda, M.; Kimura, M.; Hama, Y.; Uchida, M.; Kimura, Y. Structural Features of N-Glycans of Seaweed Glycoproteins: Predominant Occurrence of High-Mannose Type N-Glycans in Marine Plants. Biosci. Biotechnol. Biochem. 2012, 76, 1996-1998. [CrossRef]

31. Kimura, N.; Uchida, M.; Nishimura, S.; Yamaguchi, H. Promotion of Polypeptide Folding by Interactions with Asn-Glycans. J. Biochem. 1998, 124, 857-862. [CrossRef] [PubMed]

32. Mori, T.; O'Keefe, B.; Sowder, R.; Bringans, S.; Gardella, R.; Berg, S.; Cochran, P.; Turpin, J.; Buckheit, R.; McMahon, J.; et al. Isolation and Characterization of Griffithsin, a Novel HIV-Inactivating Protein, from the Red Alga Griffithsia sp. J. Biol. Chem. 2005, 280, 9345-9353. [CrossRef] [PubMed]

33. Chaves, R.; Silva, S.; Neto, L.; Carneiro, R.; Silva, A.; Sampaio, A.; Sousa, B.; Cabral, M.; Videira, P.; Teixeira, E.; et al. Structural Characterization of Two Isolectins from the Marine Red Alga solieria Filiformis (Kützing) P.W. Gabrielson and Their Anticancer Effect on MCF-7 Breast Cancer Cells. Int. J. Biol. Macromol. 2018, 107, 1320-1329. [CrossRef]

34. Mu, J.; Hirayama, M.; Sato, Y.; Morimoto, K.; Hori, K. A Novel High-Mannose Specific Lectin from the Green Alga Halimeda renschiit Exhibits a Potent Anti-Influenza Virus Activity through High-Affinity Binding to the Viral Hemagglutinin. Mar. Drugs 2017, 15, 255. [CrossRef]

35. Fernández, P.; Ciancia, M.; Estevez, J. Cell Wall Variability in the Green Seaweed Codium vermilara (Bryopsidales Chlorophyta) from the Argentine Coast. J. Phycol. 2011, 47, 802-810. [CrossRef] [PubMed]

36. Estevez, J.; Fernández, P.; Kasulin, L.; Dupree, P.; Ciancia, M. Chemical and in Situ Characterization of Macromolecular Components of the Cell Walls from the Green Seaweed Codium fragile. Glycobiology 2009, 19, 212-228. [CrossRef]

37. Yang, D.; Wang, J.; Bao, Y.; An, L. Purification and Characterization of Ulva pertusa Kjellm Alkaline Phosphatase. Prep. Biochem. Biotechnol. 2003, 33, 113-123. [CrossRef]

38. Ünlü, E.; Ünüvar, Ö.; Aydın, M. Identification of Alternative Oxidase Encoding Genes in Caulerpa cylindracea by de Novo RNA-Seq Assembly Analysis. Mar. Genom. 2019, 46, 41-48. [CrossRef]

39. Matsubara, K.; Hori, K.; Matsuura, Y.; Miyazawa, K. A Fibrinolytic Enzyme from a Marine Green Alga, Codium latum. Phytochemistry 1999, 52, 993-999. [CrossRef]

40. Choi, J.; Sapkota, K.; Park, S.; Kim, S.; Kim, S. Thrombolytic, Anticoagulant and Antiplatelet Activities of Codiase, a Bi-Functional Fibrinolytic Enzyme from Codium fragile. Biochimie 2013, 95, 1266-1277. [CrossRef]

41. Tee, M.; Yong, Y.; Rodrigues, K.; Thau, W.; Yong, L. Growth Rate Analysis and Protein Identification of Kappaphycus alvarezii (Rhodophyta, Gigartinales) under pH Induced Stress Culture. Aquac. Rep. 2015, 2, 112-116. [CrossRef]

42. Harnedy, P.; Fitzgerald, R. Bioactive Proteins, Peptides, and Amino Acids from Macroalgae. J. Phycol. 2011, 47, 218-232. [CrossRef] [PubMed]

43. Paiva, L.; Lima, E.; Patarra, R.; Neto, A.; Baptista, J. Edible Azorean Macroalgae as Source of Rich Nutrients with Impact on Human Health. Food Chem. 2014, 164, 128-135. [CrossRef]

44. Cermeño, M.; Kleekayai, T.; Amigo-Benavent, M.; Harnedy-Rothwell, P.; FitzGerald, R.J. Current Knowledge on the Extraction, Purification, Identification, and Validation of Bioactive Peptides from Seaweed. Electrophoresis 2020, 41, 1694-1717. [CrossRef]

45. García-Cañas, V.; Simó, C.; Herrero, M.; Ibáñez, E.; Cifuentes, A. Present and Future Challenges in Food Analysis: Foodomics. Anal. Chem. 2012, 84, 10150-10159. [CrossRef] [PubMed]

46. Bleakley, S.; Hayes, M. Algal Proteins: Extraction, Application, and Challenges Concerning Production. Foods 2017, 6, 33. [CrossRef] [PubMed]

47. Pangestuti, R.; Kim, S. Seaweed Proteins, Peptides, and Amino Acids. In Seaweed Sustainability: Food and Non-Food Applications; Elsevier Inc.: Amsterdam, The Netherlands, 2015; pp. 125-140. [CrossRef]

48. Guedes, A.; Amaro, H.; Sousa-Pinto, I.; Malcata, F. Applications of Spent Biomass. In Biofuels from Algae; Elsevier Inc.: Amsterdam, The Netherlands, 2013; pp. 205-233. [CrossRef]

49. Bondu, S.; Bonnet, C.; Gaubert, J.; Deslandes, É.; Turgeon, S.; Beaulieu, L. Bioassay-Guided Fractionation Approach for Determination of Protein Precursors of Proteolytic Bioactive Metabolites from Macroalgae. J. Appl. Phycol. 2015, 27, $2059-2074$. [CrossRef]

50. Øverland, M.; Mydland, L.; Skrede, A. Marine Macroalgae as Sources of Protein and Bioactive Compounds in Feed for Monogastric Animals. J. Sci. Food Agric. 2019, 99, 13-24. [CrossRef] [PubMed]

51. Garcia-Vaquero, M.; Hayes, M. Red and Green Macroalgae for Fish and Animal Feed and Human Functional Food Development. Food Rev. Int. 2015, 32, 15-45. [CrossRef]

52. Foegeding, E.; Davis, J. Food Protein Functionality: A Comprehensive Approach. Food Hydrocoll. 2011, 25, 1853-1864. [CrossRef]

53. Bouwhuis, M.; Sweeney, T.; Mukhopadhya, A.; McDonnell, M.; O’Doherty, J. Maternal Laminarin Supplementation Decreases Salmonella typhimurium Shedding and Improves Intestinal Health in Piglets Following an Experimental Challenge with $S$. typhimurium Post-Weaning. Anim. Feed. Sci. Technol. 2017, 223, 156-168. [CrossRef]

54. Sweeney, T.; Meredith, H.; Ryan, M.; Gath, V.; Thornton, K.; O’Doherty, J. Effects of Ascophyllum nodosum Supplementation on Campylobacter jejuni Colonisation, Performance and Gut Health Following an Experimental Challenge in 10 Day Old Chicks. Innov. Food Sci. Emerg. Technol. 2016, 37, 247-252. [CrossRef]

55. Vatsos, I.; Rebours, C. Seaweed Extracts as Antimicrobial Agents in Aquaculture. J. Appl. Phycol. 2015, 27, 2017-2035. [CrossRef] 
56. Sekar, S.; Chandramohan, M. Phycobiliproteins as a Commodity: Trends in Applied Research, Patents and Commercialization. J. Appl. Phycol. 2008, 20, 113-136. [CrossRef]

57. Smit, A. Medicinal and Pharmaceutical Uses of Seaweed Natural Products: A Review. J. Appl. Phycol. 2004, 16, 245-262. [CrossRef]

58. Murray, B.; Fitzgerald, R. Angiotensin Converting Enzyme Inhibitory Peptides Derived from Food Proteins: Biochemistry, Bioactivity and Production. Curr. Pharm. Des. 2007, 13, 773-791. [CrossRef]

59. Meisel, H. Multifunctional Peptides Encrypted in Milk Proteins. BioFactors 2004, 21, 55-61. [CrossRef]

60. Xu, W.; Liao, X.; Xu, S.; Diao, J.; Du, B.; Zhou, X.; Pan, S. Isolation, Structure Determination, and Synthesis of Galaxamide, a Rare Cytotoxic Cyclic Pentapeptide from a Marine Algae Galaxaura filamentosa. Org. Lett. 2008, 10, 4569-4572. [CrossRef]

61. Harnedy, P.; FitzGerald, R. In Vitro Assessment of the Cardioprotective, Anti-Diabetic and Antioxidant Potential of Palmaria palmata Protein Hydrolysates. J. Appl. Phycol. 2013, 25, 1793-1803. [CrossRef]

62. Furuta, T.; Miyabe, Y.; Yasui, H.; Kinoshita, Y.; Kishimura, H. Angiotensin I Converting Enzyme Inhibitory Peptides Derived from Phycobiliproteins of Dulse Palmaria palmata. Mar. Drugs 2016, 14, 32. [CrossRef]

63. Cha, S. Screening of Extracts from Marine Green and Brown Algae in Jeju for Potential Marine Angiotensin-I Converting Enzyme (ACE) Inhibitory Activity. J. Korean Soc. Food Sci. Nutr. 2006, 35, 307-314. [CrossRef]

64. Saito, M. Antihypertensive Effect of Nori-Peptides Derived from Red Alga Porphyra yezoensis in Hypertensive Patients. Am. J. Hypertens. 2002, 15, A210. [CrossRef]

65. Sato, M.; Oba, T.; Yamaguchi, T.; Nakano, T.; Kahara, T.; Funayama, K.; Kobayashi, A.; Nakano, T. Antihypertensive Effects of Hydrolysates of Wakame (Undaria pinnatifida) and Their Angiotensin-I-Converting Enzyme Inhibitory Activity. Ann. Nutr. Metab. 2002, 46, 259-267. [CrossRef]

66. Maehre, H. Seaweed Proteins-How to Get to Them? Effects of Processing on Nutritional Value, Bioaccessibility and Extractability. Ph.D. Thesis, Faculty of Biosciences, Fisheries and Economics, Norwegian College of Fishery Science, Tromsø, Norway, 2015.

67. Domozych, D. Algal Cell Walls. eLS 2019, 1-11. [CrossRef]

68. Weinbreck, F.; Nieuwenhuijse, H.; Robijn, G.; de Kruif, C. Complexation of Whey Proteins with Carrageenan. J. Agric. Food Chem. 2004, 52, 3550-3555. [CrossRef] [PubMed]

69. Veide Vilg, J.; Undeland, I. PH-Driven Solubilization and Isoelectric Precipitation of Proteins from the Brown Seaweed Saccharina latissima-Effects of Osmotic Shock, Water Volume and Temperature. J. Appl. Phycol. 2017, 29, 585-593. [CrossRef] [PubMed]

70. Kadam, S.; Tiwari, B.; O’Donnell, C. Application of Novel Extraction Technologies for Bioactives from Marine Algae. J. Agric. Food Chem. 2013, 61, 4667-4675. [CrossRef]

71. Abreu, T.; Monteiro, V.; Martins, A.; Teles, F.; Rivanor, R.; Mota, É.; Macedo, D.S.; de Vasconcelos, S.; Honório, J.E.R., Jr.; Benevides, N. Involvement of the Dopaminergic System in the Antidepressant-like Effect of the Lectin Isolated from the Red Marine Alga Solieria filiformis in Mice. Int. J. Biol. Macromol. 2018, 111, 534-541. [CrossRef] [PubMed]

72. Vasconcelos, M.; Arruda, F.; Carneiro, V.; Silva, H.; Nascimento, K.; Sampaio, A.; Cavada, B.; Teixeira, E.; Henriques, M.; Pereira, M. Effect of Algae and Plant Lectins on Planktonic Growth and Biofilm Formation in Clinically Relevant Bacteria and Yeasts. BioMed Res. Int. 2014, 2014, 365272. [CrossRef]

73. Leite, Y.; Silva, L.; Amorim, R.; Freire, E.; Jorge, D.; Grangeiro, T.; Benevides, N. Purification of a Lectin from the Marine Red Alga Gracilaria ornata and Its Effect on the Development of the Cowpea Weevil Callosobruchus maculatus (Coleoptera: Bruchidae). Biochim. Biophys. Acta Gen. Subj. 2005, 1724, 137-145. [CrossRef]

74. Fleurence, J.; Massiani, L.; Guyader, O.; Mabeau, S. Use of Enzymatic Cell Wall Degradation for Improvement of Protein Extraction from Chondrus crispus, Gracilaria verrucosa and Palmaria palmata. J. Appl. Phycol. 1995, 7, 393-397. [CrossRef]

75. Vásquez, V.; Martínez, R.; Bernal, C. Enzyme-Assisted Extraction of Proteins from the Seaweeds Macrocystis pyrifera and Chondracanthus chamissoi: Characterization of the Extracts and Their Bioactive Potential. J. Appl. Phycol. 2019, 31, 1999-2010. [CrossRef]

76. Burlot, A.; Bedoux, G. Response Surface Methodology for Enzyme-Assisted Extraction of Water- Soluble Antiviral Compounds from the Proliferative Macroalga Solieria chordalis. Enzym. Eng. 2016, 5, 1000148. [CrossRef]

77. Harnedy, P.; Fitzgerald, R. Extraction of Protein from the Macroalga Palmaria palmata. LWT Food Sci. Technol. 2013, 51, 375-382. [CrossRef]

78. Vilkhu, K.; Mawson, R.; Simons, L.; Bates, D. Applications and Opportunities for Ultrasound Assisted Extraction in the Food Industry-A Review. Innov. Food Sci. Emerg. Technol. 2008, 9, 161-169. [CrossRef]

79. Vilkhu, K.; Manasseh, R.; Mawson, R.; Ashokkumar, M. Ultrasonic Recovery and Modification of Food Ingredients. In Ultrasound Technologies for Food and Bioprocessing; Food Engineering Series; Springer: New York, NY, USA, 2011; pp. 345-368. [CrossRef]

80. Grosso, C.; Valentão, P.; Ferreres, F.; Andrade, P. Alternative and Efficient Extraction Methods for Marine-Derived Compounds. Mar. Drugs 2015, 13, 3182-3230. [CrossRef]

81. Wu, H.; Hulbert, G.; Mount, J. Effects of Ultrasound on Milk Homogenization and Fermentation with Yogurt Starter. Innov. Food Sci. Emerg. Technol. 2000, 1, 211-218. [CrossRef]

82. Chemat, F.; Zill-e-Huma; Khan, M.K. Applications of Ultrasound in Food Technology: Processing, Preservation and Extraction. Ultrason. Sonochem. 2011, 18, 813-835. [CrossRef]

83. Mittal, R.; Tavanandi, H.; Mantri, V.; Raghavarao, K. Ultrasound Assisted Methods for Enhanced Extraction of Phycobiliproteins from Marine Macro-Algae, Gelidium pusillum (Rhodophyta). Ultrason. Sonochem. 2017, 38, 92-103. [CrossRef] 
84. Fleurence, J.; le Coeur, C.; Mabeau, S.; Maurice, M.; Landrein, A. Comparison of Different Extractive Procedures for Proteins from the Edible Seaweeds Ulva rigida and Ulva rotundata. J. Appl. Phycol. 1995, 7, 577-582. [CrossRef]

85. Harrysson, H.; Hayes, M.; Eimer, F.; Carlsson, N.; Toth, G.; Undeland, I. Production of Protein Extracts from Swedish Red, Green, and Brown Seaweeds, Porphyra umbilicalis Kützing, Ulva lactuca Linnaeus, and Saccharina latissima (Linnaeus) J. V. Lamouroux Using Three Different Methods. J. Appl. Phycol. 2018, 30, 3565-3580. [CrossRef]

86. Robin, A.; Kazir, M.; Sack, M.; Israel, A.; Frey, W.; Mueller, G.; Livney, Y.; Golberg, A. Functional Protein Concentrates Extracted from the Green Marine Macroalga Ulva sp. by High Voltage Pulsed Electric Fields and Mechanical Press. ACS Sustain. Chem. Eng. 2018, 6, 13696-13705. [CrossRef]

87. Sticher, O. Natural Product Isolation. Nat. Prod. Rep. 2008, 25, 517-554. [CrossRef]

88. Rostagno, M.; Villares, A.; Guillamón, E.; García-Lafuente, A.; Martínez, J. Sample Preparation for the Analysis of Isoflavones from Soybeans and Soy Foods. J. Chromatogr. A 2009, 1216, 2-29. [CrossRef] [PubMed]

89. Romanik, G.; Gilgenast, E.; Przyjazny, A.; Kamiński, M. Techniques of Preparing Plant Material for Chromatographic Separation and Analysis. J. Biochem. Biophys. Methods 2007, 70, 253-261. [CrossRef] [PubMed]

90. Pathak, Y.; Wang, L. Advances in Extraction of Plant Products in Nutraceutical Processing. In Handbook of Nutraceuticals Volume II; CRC Press: Boca Raton, FL, USA, 2011; pp. 15-52. [CrossRef]

91. Lu, J.; Feng, X.; Han, Y.; Xue, C. Optimization of Subcritical Fluid Extraction of Carotenoids and Chlorophyll a from Laminaria japonica Aresch by Response Surface Methodology. J. Sci. Food Agric. 2014, 94, 139-145. [CrossRef]

92. Herrero, M.; Castro-Puyana, M.; Mendiola, J.; Ibañez, E. Compressed Fluids for the Extraction of Bioactive Compounds. TrAC Trends Anal. Chem. 2013, 43, 67-83. [CrossRef]

93. Quitain, A.; Kai, T.; Sasaki, M.; Goto, M. Supercritical Carbon Dioxide Extraction of Fucoxanthin from Undaria pinnatifida. J. Agric. Food Chem. 2013, 61, 5792-5797. [CrossRef]

94. Careri, M.; Furlattini, L.; Mangia, A.; Musci, M.; Anklam, E.; Theobald, A.; von Holst, C. Supercritical Fluid Extraction for Liquid Chromatographic Determination of Carotenoids in Spirulina pacifica Algae: A Chemometric Approach. J. Chromatogr. A 2001, 912, 61-71. [CrossRef]

95. Mendes, R.; Nobre, B.; Cardoso, M.; Pereira, A.; Palavra, A. Supercritical Carbon Dioxide Extraction of Compounds with Pharmaceutical Importance from Microalgae. Inorg. Chim. Acta 2003, 356, 328-334. [CrossRef]

96. Khaw, K.; Parat, M.; Shaw, P.; Falconer, J. Solvent Supercritical Fluid Technologies to Extract Bioactive Compounds from Natural Sources: A Review. Molecules 2017, 22, 1186. [CrossRef] [PubMed]

97. Manjare, S.; Dhingra, K. Supercritical Fluids in Separation and Purification: A Review. Mater. Sci. Energy Technol. 2019, 2, 463-484. [CrossRef]

98. Gallego, R.; Bueno, M.; Herrero, M. Sub- and Supercritical Fluid Extraction of Bioactive Compounds from Plants, Food-byProducts, Seaweeds and Microalgae-An Update. Trends Anal. Chem. 2019, 116, 198-213. [CrossRef]

99. Mohd, N.; Draman, S.; Salleh, M.; Yusof, N. Dissolution of Cellulose in Ionic Liquid: A Review. In AIP Conference Proceedings; American Institute of Physics Inc.: College Park, MD, USA, 2017; Volume 1809. [CrossRef]

100. Swatloski, R.; Spear, S.; Holbrey, J.; Rogers, R. Dissolution of Cellose with Ionic Liquids. J. Am. Chem. Soc. 2002, 124, 4974-4975. [CrossRef] [PubMed]

101. Tang, B.; Bi, W.; Tian, M.; Row, K. Application of Ionic Liquid for Extraction and Separation of Bioactive Compounds from Plants. J. Chromatogr. B Anal. Technol. Biomed. Life Sci. 2012, 904, 1-21. [CrossRef]

102. Angell, A.; Paul, N.; de Nys, R. A Comparison of Protocols for Isolating and Concentrating Protein from the Green Seaweed Ulva ohnoi. J. Appl. Phycol. 2017, 29, 1011-1026. [CrossRef]

103. Kumar, P.; Sharma, N.; Ranjan, R.; Kumar, S.; Bhat, Z.; Jeong, D. Perspective of Membrane Technology in Dairy Industry: A Review. Asian-Australas. J. Anim. Sci. 2013, 26, 1347-1358. [CrossRef] [PubMed]

104. Shao, P.; Chen, M.; Pei, Y.; Sun, P. In Intro Antioxidant Activities of Different Sulfated Polysaccharides from Chlorophytan Seaweeds Ulva fasciata. Int. J. Biol. Macromol. 2013, 59, 295-300. [CrossRef]

105. Araki, C. Some Recent Studies on the Polysaccharides of Agarophytes. In Proceedings of the Fifth International Seaweed Symposium, Halifax, NS, Canada, 25-28 August 1966; Elsevier: Amsterdam, The Netherlands, 1966; pp. 3-17. [CrossRef]

106. Saluri, M.; Kaldmäe, M.; Tuvikene, R. Extraction and Quantification of Phycobiliproteins from the Red Alga Furcellaria lumbricalis. Algal Res. 2019, 37, 115-123. [CrossRef]

107. Senthilkumar, N.; Suresh, V.; Thangam, R.; Kurinjimalar, C.; Kavitha, G.; Murugan, P.; Rengasamy, R. Isolation and Characterization of Macromolecular Protein R-Phycoerythrin from Portieria hornemannii. Int. J. Biol. Macromol. 2013, 55, 150-160. [CrossRef]

108. Niu, J.; Xu, M.; Wang, G.; Zhang, K.; Peng, G. Comprehensive Extraction of Agar and R-Phycoerythrin from Gracilaria lemaneiformis (Bangiales, Rhodophyta). Indian J. Geo-Mar. Sci. 2013, 42, 21-28.

109. Jong, L.; Thien, V.; Yong, Y.; Rodrigues, K.; Yong, W. Micropropagation and Protein Profile Analysis by SDS-PAGE of Gracilaria changii (Rhodophyta, Solieriaceae). Aquac. Rep. 2015, 1, 10-14. [CrossRef]

110. Rosni, M.; Fisal, A.; Azwan, A.; Chye, F.Y.; Matanjun, P. Crude Proteins, Total Soluble Proteins, Total Phenolic Contents and SDS-PAGE Profile of Fifteen Varieties of Seaweed from Semporna, Sabah, Malaysia. Int. Food Res. J. 2015, 22, 1483-1493. 
111. Tsuji, A.; Kuwamura, S.; Shirai, A.; Yuasa, K. Identification and Characterization of a 25 KDa Protein That Is Indispensable for the Efficient Saccharification of Eisenia bicyclis in the Digestive Fluid of Aplysia kurodai. PLoS ONE 2017, 12, e0170669. [CrossRef] [PubMed]

112. Garcia-Vaquero, M.; Lopez-Alonso, M.; Hayes, M. Assessment of the Functional Properties of Protein Extracted from the Brown Seaweed Himanthalia elongata (Linnaeus) S. F. Gray. Food Res. Int. 2017, 99, 971-978. [CrossRef] [PubMed]

113. Go, H.; Hwang, H.; Nam, T. Glycoprotein Extraction from Laminaria japonica Promotes IEC-6 Cell Proliferation. Int. J. Mol. Med. 2009, 24, 819-824. [CrossRef]

114. Choi, Y.; Yamaguchi, K.; Oda, T.; Nam, T. Chemical and Mass Spectrometry Characterization of the Red Alga Pyropia yezoensis Chemoprotective Protein (PYP): Protective Activity of the N-Terminal Fragment of PYP1 against Acetaminophen-Induced Cell Death in Chang Liver Cells. Int. J. Mol. Med. 2015, 35, 271-276. [CrossRef]

115. Fernández-Segovia, I.; Lerma-García, M.; Fuentes, A.; Barat, J. Characterization of Spanish Powdered Seaweeds: Composition, Antioxidant Capacity and Technological Properties. Food Res. Int. 2018, 111, 212-219. [CrossRef]

116. Vieira, E.; Soares, C.; Machado, S.; Correia, M.; Ramalhosa, M.; Oliva-Teles, M.; Paula Carvalho, A.; Domingues, V.; Antunes, F.; Oliveira, T.; et al. Seaweeds from the Portuguese Coast as a Source of Proteinaceous Material: Total and Free Amino Acid Composition Profile. Food Chem. 2018, 269, 264-275. [CrossRef]

117. Kazir, M.; Abuhassira, Y.; Robin, A.; Nahor, O.; Luo, J.; Israel, A.; Golberg, A.; Livney, Y. Extraction of Proteins from Two Marine Macroalgae, Ulva sp. and Gracilaria sp., for Food Application, and Evaluating Digestibility, Amino Acid Composition and Antioxidant Properties of the Protein Concentrates. Food Hydrocoll. 2019, 87, 194-203. [CrossRef]

118. Abdollahi, M.; Axelsson, J.; Carlsson, N.; Nylund, G.; Albers, E.; Undeland, I. Effect of Stabilization Method and Freeze/ThawAided Precipitation on Structural and Functional Properties of Proteins Recovered from Brown Seaweed (Saccharina latissima). Food Hydrocoll. 2019, 96, 140-150. [CrossRef]

119. Kumar, K.; Ganesan, K.; Selvaraj, K.; Rao, P. Studies on the Functional Properties of Protein Concentrate of Kappaphycus alvarezii (Doty) Doty-An Edible Seaweed. Food Chem. 2014, 153, 353-360. [CrossRef] [PubMed]

120. Romarís-Hortas, V.; Bermejo-Barrera, P.; Moreda-Piñeiro, A. Ultrasound-Assisted Enzymatic Hydrolysis for Iodinated Amino Acid Extraction from Edible Seaweed before Reversed-Phase High Performance Liquid Chromatography-Inductively Coupled Plasma-Mass Spectrometry. J. Chromatogr. A 2013, 1309, 33-40. [CrossRef] [PubMed] 